FIU Law Review

Fall 2009

\title{
Lucas Leaves Room for Categorical Defenses for Regulations of Wetlands that Are Critical to Water Resources and Essential for Public Drinking
}

Shannon O’Shea

Follow this and additional works at: https://ecollections.law.fiu.edu/lawreview

Part of the Other Law Commons

Online ISSN: 2643-7759

Recommended Citation

Shannon O'Shea, Lucas Leaves Room for Categorical Defenses for Regulations of Wetlands that Are Critical to Water Resources and Essential for Public Drinking, 5 FIU L. Rev. 243 (2009).

DOI: https://dx.doi.org/10.25148/lawrev.5.1.15

This Comment is brought to you for free and open access by eCollections. It has been accepted for inclusion in FIU Law Review by an authorized editor of eCollections. For more information, please contact lisdavis@fiu.edu. 


\title{
Lucas Leaves Room for Categorical Defenses for Regulations of Wetlands that Are Critical to Water Resources and Essential for Public Drinking
}

\author{
Shannon O'Shea

\section{INTRODUCTION}

Imagine living in a place where you do not have to question whether the water you are drinking on a daily basis is safe. Each day you or your children consume water that you assume is nontoxic. Suddenly, you realize that the water you or your children drink is vulnerable to bacterial and chemical contamination. Your drinking water is at risk of containing chemicals that cause cancer, and pathogens that produce parasitic diseases. Millions of people in your community, as well as future generations, are at risk of life-threatening diseases because of the actions of private individuals. Would you want the government to protect you and your family from drinking contaminated water, or would you want the government to allow individuals to pollute critical water resources by dredging and filling wetlands?

Freshwater on land is one of the most important resources on the planet, and it is essential for human existence. ${ }^{1}$ Most of the planet's water is found in the earth's oceans. Saltwater constitutes $97.5 \%$ of water, whereas freshwater in the earth's glaciers only constitutes $2.5 \%$. $^{2}$ No more than eight thousandths of potable water is found on land, and it is this resource that is one of the most vital resources necessary for human existence. ${ }^{3}$ The freshwater ecosystems have been considerably changed and disturbed by humans. ${ }^{4}$ Threatened freshwater ecosystems include wetlands. Governmental regulations are designed to protect wetlands; however, wetlands are still being destroyed, resulting in one of the most vital resources becoming depleted.

\footnotetext{
* B.S. Florida State University; J.D. Florida International University College of Law. I thank Professor Carlton Waterhouse, my faculty advisor, for his thoughtful comments and guidance. A very special thanks to my husband, Travis Darsch, and my parents, Sean and Barbara O'Shea, for their neverending support and encouragement.

1 Robert V. Percival et al., EnVironmental Regulation: LaW, SCIENCE, AND Policy 581 (Vicki Been \& Erwin Chemerinsky ed., Aspen Publishers 2006).

Id.

Id.

4 See id. (addressing that humans have competed to trap water, pollute it, feed it to livestock, and channel it onto farms, which is the biggest single use of water).
} 
Wetlands play a critical role in preserving water quality and quantity. Approximately 221 million acres of wetlands ${ }^{6}$ once formed an immense support system for the United States. ${ }^{7}$ Throughout the history of the United States, wetlands have been cleared, drained, and developed. ${ }^{8}$ Scientists estimate that $53 \%$ of wetland losses occurred between the 1780s and 1980s due to agriculture and development. ${ }^{9}$ In the past, many people considered wetlands a nuisance because wetlands prevented agriculture, precluded development, obstructed travel, and attracted insects that ate nearby crops. ${ }^{10}$ Scientists later learned about the importance of wetlands and significant protection efforts began in the 1960s; however, wetlands continued to disappear. $^{11}$

Florida has lost more acres of wetlands than any other state. ${ }^{12}$ Florida's total land area is approximately 35 million acres. ${ }^{13}$ At one point in time, $60 \%$ of Florida was wetlands. ${ }^{14}$ Unfortunately, Florida only had about 11.4 million acres of wetlands by the 1990 s, which represented a loss of almost $44 \%$ of wetlands. ${ }^{15}$ Plans to drain Florida date back to its statehood in 1845 when the state legislature asked Congress to survey Florida. ${ }^{16}$ Congress authorized Buckingham Smith to study Florida, which led to Smith's

5 JaCk E. DAVIS \& RAYMond ARSEnAult, PARAdise Lost? THE EnVIRONMENTAL History of FLORIDA 133 (University Press of Florida 2005).

6 Until the early twentieth century, wetlands were defined as places unsuitable for agriculture because of the moisture on the land. In the 1950s, the scientific community began to use the term "wetlands" instead of wet land. The United States Army Corps of Engineers refers to wetlands as "those areas that are inundated or saturated by surface or ground water at a frequency and duration sufficient to support, and that under normal circumstances do support, a prevalence of vegetation typically adapted for life in saturated soil conditions." Id. at 114; see also 33 C.F.R. § 328.3(b) (2010) (United States Army Corps of Engineers' definition of wetlands).

7 Ann Vileisis, Discovering the UnKnown Landscape: A History of America's WETLANDS 11 (Island Press 1998).

$8 \quad I d$. at 4 .

$9 \quad I d$. at 3

10 DAVIS \& ARSENAUlT, supra note 5, at 121-22; see also VILEISIS, supra note 7, at 7 (describing how the perception of swamps and marshes for centuries as worthless and troublesome led to governmental policies encouraging citizens to drain swamps by giving land grants and subsidies for the promotion of drainage).

11 Wetlands perform water cleansing functions, reduce shoreline erosion, protect water tables from saltwater intrusion, and numerous threatened and endangered species depend on them for survival. John J. Fumero, Environmental Law: 1994 Survey of Florida Law-At a Crossroads in Natural Resource Protection and Management in Florida, 19 NOVA L. REV. 77, 78 (1994); see also VILEISIS, supra note 7 , at 4-8 (explaining that, although wetlands provide wildlife habitat, water quality, and flood protection, a centuries long tradition and powerful bias favoring agriculture and development persist despite growing awareness about the values of wetland ecosystems).

12 DAVIS \& ARSENAULT, supra note 5, at 131.

13 Id. at 122.

14 Id. at 131 .

15 Id.

16 Id. at 122. 
1848 report establishing that Florida was "utter worthlessness to civilized man," and that draining the Everglades, along with drying out South Florida by deepening rivers and digging canals, would be a reasonable decision. Under the Swamp Land Act of 1850, the federal government deeded most of the Everglades to the State of Florida on a condition that Smith's plans be followed. $^{18}$ Florida laid claim to approximately 22 million acres of wetlands under the Swamp Land Act of $1850{ }^{19}$ Congress used the proceeds to fund their "reclamation," which meant modifying the landscape for agricultural and urban development. ${ }^{20}$

Florida's wetlands did not remain under state control. ${ }^{21}$ Florida gave away and sold vast amounts of wetlands. ${ }^{22}$ Florida granted wetlands to corporations in return for railroad construction, and either sold or gave millions of acres of swampland away to attract people and money. ${ }^{23}$ In 1881, Hamilton Disston purchased 4 million acres of Florida swampland for the mere sum of one million dollars. ${ }^{24}$ Granting wetlands to private individuals created unforeseen problems of regulation.

In the 1970s, Congress created a provision known as section 404 of the Clean Water Act giving the United States Army Corps of Engineers authority to issue or deny permits for discharges of dredged or fill material in regulated wetlands. ${ }^{25}$ The Fifth Amendment to the Constitution states private property shall not "be taken for public use without just compensation." 26 A per se regulatory taking in violation of the Fifth Amendment may be found when regulations completely deprive an owner of all economically viable use of her property, unless, "background principles of nuisance and property law" independently restrict the owner's intended use of the property or when government mandates "permanent physical invasions of property." The Army Corps of Engineers is now in the difficult position of issuing permits because of the competing interests between developers of private property and environmentalists deeply concerned about the loss of wet-

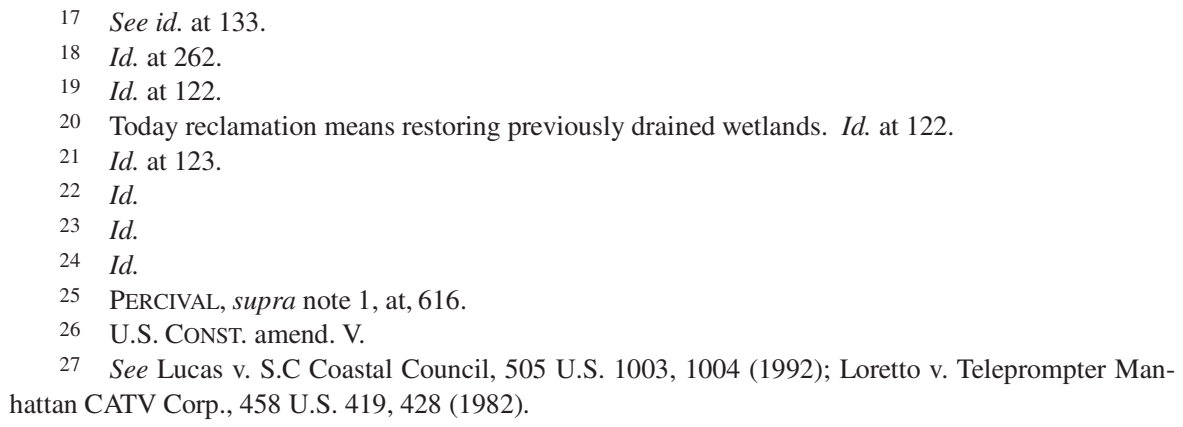


lands. ${ }^{28}$ The denial of permits by the Army Corps of Engineers can lead to an unconstitutional taking of property. ${ }^{29}$

Courts have traditionally upheld regulations preventing owners from using their land in a way that injures the community even when the regulations severely limit land development by analogy to nuisance laws. ${ }^{30} \mathrm{Re}-$ cently, however, some courts have suggested or ruled that when wetland regulations prevent all land development, compensation is owed. ${ }^{31}$ In Florida Rock Industries, Inc. v. United States, a permit applicant filed a regulatory takings challenge against the Army Corps of Engineers in the early 1980s for the denial of a section 404 permit, which resulted in a settlement of $\$ 21$ million in $2001 .^{32}$ Florida Rock bought land and started mining before the Clean Water Act dredge and fill permit system was created, and mining was the only economically viable use of the property. ${ }^{33}$ The property suffered a $73.1 \%$ decrease in value because of the permit denial, and Florida Rock could not recoup its investment by selling the property. ${ }^{34}$ The Florida Rock litigation was a powerful reminder of the expensive consequences of the Army Corps of Engineers' permitting decisions. ${ }^{35}$

After Florida Rock, the Army Corps of Engineers issued permits to members of the limestone mining industry to conduct mining in water conservation areas in Miami, Florida, which would directly destroy wetlands and potentially contaminate millions of gallons of drinking water drawn daily from the Biscayne Aquifer. ${ }^{36}$ In Sierra Club v. Flowers, environmental organizations brought an action against the Army Corps of Engineers seeking declaratory and injunctive relief from the issuances of permits in water conservation areas. ${ }^{37}$ The district court suggested that the threat of additional takings claims, such as Florida Rock, was apparent in the permitting decision, and also noted there was a high likelihood that procedural

\footnotetext{
28 DAVIS \& ARSENAULT, supra note 5, at 129.

29 Florida Rock Indus. Inc., v. United States, 45 Fed. Cl. 21 (1999) (holding a regulatory taking occurred when Florida Rock was denied a mining permit).

30 Gardner v. N.J. Pinelands Comm'n, 593 A.2d 251 (N.J. 1991); Presbytery of Seattle v. King County, 787 P.2d 907 (Wash. 1990); Just v. Marinette County, 201 N.W.2d 761 (Wis. 1972).

31 Tulare Lake Basin Water Storage Dist. v. United States, 49 Fed. Cl. 313 (2001); Palm Beach Isles Assoc. v. United States, 231 F.3d 1354 (Fed. Cir. 2000); Laguna Gatuna Inc. v. United States, 50 Fed. Cl. 336 (2001); Florida Rock, 45 Fed. Cl. 21 (1999).

32 Florida Rock, 45 Fed. Cl. 21 (1999).

33 Id.

34 Florida Rock, 45 Fed. Cl. 21 (1999); Sierra Club v. Flowers, 423 F. Supp. 2d 1273, 1301 (S.D. Fla. 2006), order supplemented by Sierra Club v. Strock, 495 F. Supp. $2 d 1188$ (S.D. Fla. 2007), vacated by Sierra Club v. Van Antwerp, 526 F.3d 1353 (11th Cir. 2008).

35 See Sierra Club v. Flowers, 423 F. Supp. 2d 1273, 1302 (S.D. Fla. 2006)

36 Id.

37 Id.
} 
safeguards in the Clean Water Act and other Acts were overlooked because of the threat of additional takings litigation. ${ }^{38}$

This Comment argues for a categorical defense to takings liability for regulations of wetlands that are critical to water resources and essential for public drinking. Categorical defenses to takings liability established in a leading case, Lucas v. South Carolina Coastal Council, leave room for regulations of wetlands that are critical to water resources and essential for public drinking. This Comment argues that governmental regulations of wetlands that protect public health and safety should be immune from takings liability even when the regulations destroy property value.

The goal of this Comment is to demonstrate the importance of wetlands and the reasons why regulations of wetlands that are critical to water resources and essential for public drinking should be immune from takings liability. Part II of this Comment further explains the history of America's wetlands, and in particular the history of Florida's wetlands. It also includes the reasons for the destruction of wetlands, which include increasing population and early harmful wetland regulations. Part III focuses on efforts at the national, state, and international levels to preserve wetlands. It discusses the National Environmental Policy Act, the Clean Water Act, the "No Net Loss" of wetlands, and the Emergency Wetlands Resources Act, which all represent the initiatives taken by the federal government to preserve wetlands. The Clean Water Act is the primary authority for the federal regulation of dredging or filling wetlands. Part III later discusses initiatives taken by Florida to preserve wetlands, and it ends with a discussion on the Ramsar Convention.

Despite the growing awareness of the importance of wetlands and the many efforts to protect wetlands at the national, state, and international levels, wetlands are still threatened. Under the Clean Water Act, developers are required to obtain a permit for dredging or filling wetlands. If private property owners are denied a permit to develop wetlands, they can challenge the permit denials by claiming a regulatory taking. Part IV addresses the problem of regulatory takings, and it discusses how takings claims can threaten the effectiveness of many Acts intended to protect wetlands. It illustrates the problem of regulatory takings in Sierra Club v. Flowers and Sierra Club v. Strock. Part IV includes an in-depth discussion on Lucas v. South Carolina Coastal Council's categorical defenses to regulatory takings. Part IV argues for a categorical defense to regulations of wetlands that are critical to water resources and essential for public drinking. Part V continues to argue why Lucas v. South Carolina Coastal Council's categor-

$38 \quad$ Id. at 1287. 
ical defenses should solve the problem of regulatory takings, and suggests solutions to a few unresolved issues. This Comment concludes by restating the significance of wetlands and the reasons wetland regulations should be immune from categorical takings liability.

\section{WETLANDS - THE HISTORY AND REASONS FOR LOSS}

\section{A. A Brief History of America's Wetlands}

The United States had approximately 221 million acres of wetlands in the 1600s. ${ }^{39}$ Changes to wetlands occurred between 1600 and 1800 in the original thirteen states. ${ }^{40}$ Over the next sixty years, wetlands mainly in the Midwest and South were destroyed by the drainage and development encouraged by the Swamp Land Acts. ${ }^{41}$ The federal government later funded wetland drainage from 1860-1950, and by the 1950s over 110 million acres of wetlands were lost. ${ }^{42}$ From the 1950s to the 1970s, 9 million acres of wetlands were destroyed. From the mid- 1970s to the mid-1980s, 2.6 million acres of wetlands were destroyed. ${ }^{43}$ From 1986 to 1997, 535,500 acres of wetlands were destroyed. ${ }^{44}$ Wetlands have been drained, mined, and dredged for various purposes, such as farming (responsible for $87 \%$ of wetland losses), mosquito control, navigation, flood protection, housing developments, construction, and the extraction of groundwater. ${ }^{45}$ In the Northeast, most of the transformation of wetlands occurred in the coastal-plain states for farming, developing ports, residential housing, and to provide navigation. ${ }^{46}$ In the Midwest, agriculture was the main reason for destroying wetlands. For example, Indiana lost $85 \%$ of its wetlands for cultivation. Indiana, Missouri, Iowa, and California are the states with the most wetland losses, ranging between $87 \%$ and $91 \% .^{47}$ Although Indiana, Mis-

39 Ralph W. Tiner, In SEARCh of Swampland 108 (Rutgers University Press 2d ed. 2005) (1998).

$40 \quad I d$. at 109.

41 Id.

42 See generally Patrick Dugan, Guide to Wetlands 48 (Joanna Potts ed., Firefly Books 2005) (explaining how the United States has lost 52\% of wetlands and in some states the loss is greater).

43 TINER, supra note 39, at112.

44 Lars B. Johanson \& GlenN W. King, Statistical Abstract of the United States: 2006 225 (Diane Pub. Co. 2005) (1878).

45 TINER, supra note 39, at 109-113; see also DUGAN, supra note 42, at 48 (explaining that $80 \%$ of wetland loss has been to agriculture).

46 TINER, supra note 39, at 110 .

47 DAVIS \& ARSENAULT, supra note 5, at 131. 
souri, Iowa, and California are the states with the most wetlands losses, Florida has also lost a significant amount of wetlands. ${ }^{48}$

\section{B. A Brief History of Florida's Wetlands}

One cannot think about Florida's environmental history without also thinking about water. Florida was born from water when it emerged from the sea several million years ago. ${ }^{49}$ Florida's geology reveals that almost all of the state used to form the floor of the ocean. ${ }^{50}$ This explains why Florida's landscape is dominated by wetlands, and more than half of Florida used to consist of wetlands. ${ }^{51}$ Florida's wetlands can be categorized into river swamps, still-water swamps, freshwater marshes, saltwater marshes, and mangroves. ${ }^{52}$ These swamps and marshes were considered a nuisance because they attracted insects, were thought to be the source of diseases, and were unfit for cultivation. ${ }^{53}$ In the late nineteenth and early twentieth centuries, many believed that if the water in the Everglades was drained, farms could be established on the rich soils. ${ }^{54}$

In the early twentieth century, programs began to drain the wetlands in South Florida. In 1906, agricultural developments became possible by draining the Everglades. ${ }^{55}$

The 1906 project, led by Florida's governor, Napoleon Bonaparte Broward, took decades to complete due to engineering problems, lack of money, and the hurricanes of 1926 and 1928. ${ }^{56}$ It was not until the 1940s that the wetland "reclamation" continued in the Everglades when the Feder-

48 In Florida, the Everglades and the Big Cypress Swamp have been greatly affected by wetland alterations. Other swamps have also been destroyed. The Great Kankakee Swamp used to be 1million acres, but now hardly any of it is left. The Black Swamp was 120 miles long and 40 miles wide, but 3 million acres of it was drained and only $5 \%$ of it remains today. Swamps were thought of as nuisances because mosquitoes carrying diseases were attracted to swamps. See DUGAN, supra note 42, at 55; TINER, supra note 39, at 110 ; DAVIS \& ARSENAULT, supra note 5, at 261.

49 DAVIS \& ASENAULT, supra note 5, at 131.

$50 \quad$ Id.

51 See id. at 122-23 (Florida at one time may have had more than $60 \%$ of the state covered by wetlands).

52 Id. at 116.

53 Id. at 122.

54 Drainage received political support from Governor Napoleon Broward, and in 1906 one of the greatest attempts at reclamation in American history began by digging canals, constructing levees, and moving out the Everglades from Fort Lauderdale. EDWARD A. FERNALD \& ElizABETH D. PURDUM, ATLAS OF FLORIDA, 106 (University Press of Florida 1992).

55 DAVIS \& ARSENAUlT, supra note 5, at 144.

56 Id. at 124 
al government gave funds to the Army Corps of Engineers. ${ }^{57}$ Between 1845 and 1920, Florida lost 3.5 million acres of wetlands.

The draining of the Everglades wetlands was not only due to agriculture, but also because of flooding and development. The 1947 hurricanes flooded fifteen thousand square miles of Florida, which resulted in the Army Corps of Engineers developing a plan to prevent flooding by widening and deepening old canals, digging new canals, building massive pumps to drive water from fields into Lake Okeechobee, and creating evaporation ditches. ${ }^{59}$ The creation of Tamiami Trail highway, starting in the summer of 1915, also contributed to the drainage of the Everglades. ${ }^{60}$ The highway was created by building a route straight through the center of the Everglades, and it disrupted more than 4 million acres of land and water. ${ }^{6}$

Presently, billions of dollars are being spent to cure past mistakes of draining and destroying the Everglades. ${ }^{62}$ Recent experience demonstrates the importance of wetlands in providing water quality by performing water cleansing functions, reducing erosion, protecting water tables from saltwater intrusion, and providing a habitat for endangered species. ${ }^{63}$ Most importantly, draining wetlands affects the quantity and quality of water. ${ }^{64}$ Wetlands provide a range of services including water purification and ground-

57 Id. (explaining that during the reclamation, 700,000 acres of farmland were carved out of the Everglades).

58 Id. at 125.

59 See Allen Moriss \& JoAn Perry Morris, The Florida HandBoOK 2005-2006 509 (The Peninsular Pub. Co. 30th ed. 2005) (noting that the Hurricanes of 1926 and 1928 also created major engineering works because of the surplus water created by the hurricanes); see also FERNALD \& PURDUM, supra note 54, at 81.

60 See DAVIS \& ARSENAUlT, supra note 5, at 261 (noting that the summer of 1915 launched a road building project to create Tamiami Trail, a paved highway west from Miami to the Gulf of Mexico, then north through Fort Myers and all the way to Tampa. Tamiami Trail's route went through the center of the southern Everglades and Big Cypress Swamp); see also FERNALD \& PURDUM, supra note 54, at 105.

61 See DAVIS \& ARSENAUlT, supra note 5, at 261 (stating that Tamiami trail symbolizes the decades long movement to clear Florida of the Everglades).

62 See generally Allen Morris \& JoAn Perry Morris, The Florida Handbook 2005-2006 509 (The Peninsular Pub. Co. 30th ed. 2005) (stating that almost 50 years of experience demonstrates the need of the Everglades by people, creatures, and plants); see also DAVIS \& ARSENAULT, supra note 5 , at 124 (stating that $\$ 7.8$ billion is currently being spent by state and federal government authorities to restore the Everglades).

63 See John J. Fumero, Environmental Law: 1994 Survey of Florida Law-At A Crossroads In Natural Resource Protection And Management In Florida, 19 NovA L. REV. 77, 78 (1994); see also DAVIS \& ARSENAULT, supra note 5, at 132 (providing that increased public awareness of wetlands functions and values have led to public polices intended to protect wetlands).

64 See DAVIS \& ARSENAULT, supra note 5, at 133 (describing that the reason wetlands are wet is because of groundwater or nearby springs discharging water on the surface. Most of Florida's water supply is pumped from the ground. Pumping too much groundwater can even dry wetlands). 
water recharge. ${ }^{65}$ When water moves from a wetland into an underground aquifer, it recharges the groundwater and the water becomes cleaner than when it was on the surface due to natural filtration. ${ }^{66}$ An aquifer is a rock deposit underneath earth's surface storing underground water. ${ }^{67}$ An aquifer may consist of gravel, sandstone, sand, or limestone. Groundwater is subsurface water that moves slowly through permeable rocks and is replenished by precipitation. This groundwater is important for human consumption because once in the aquifer, the water can be drawn through wells. $^{68}$

Groundwater is the largest single supply of freshwater available for use by humans. ${ }^{69}$

Freshwater accounts for less than three percent of earth's water; accessible groundwater accounts for .31 percent. $^{70}$ Over the past fifty years, global water consumption has tripled. ${ }^{71}$ Humans are extracting water from aquifers at a greater rate than the rate of replenishment, which causes the water levels to decrease. ${ }^{72}$ Water in aquifers is decreasing at rates between two and eight meters per year in every continent. ${ }^{73}$ The impact of an increasing population is a major cause of over-pumping aquifers.

\section{America's Population Growth}

In the year 1790, the population of the United States was just under four million. ${ }^{74}$ In 2000, the population count rose to approximately 280 million. ${ }^{75}$ With this increase in population came an increase in water withdrawals. In 1940, the number of gallons of water withdrawn per day in the

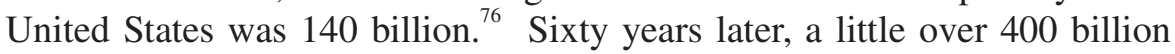

65 See Jody Freeman \& Charles D. Kolstad, Moving to Markets in Environmental REGULATION: LESSONS FROM TWENTY YEARS OF EXPERIENCE 323 (Oxford Univ. Press 2007).

66 See DUGAN, supra note 42 at 17.

67 Id.

$68 I d$.

69 See Cartographic Applications and Processing Program, http://capp.water.usgs.gov; see also Herman E. Daly \& Joshua Farley, Ecological Economics 87 (Island Press 2004) (stating that fresh water accounts for less than three percent of water on the planet. Exploited lakes account for .009 percent, rivers .0001 percent, accessible groundwater .31 percent, .01 percent in the atmosphere, .31 percent is deep groundwater, and about 2 percent in earth's polar ice caps and glaciers).

70 See DALY \& FARLEY, supra note 69 , at 87.

71 Id.

72 Id.

73 Id. at 117.

74 JOHANSON \& KING, supra note 44, at 8 (stating that the population was exactly 3,929,214 million people).

75 See id. (stating that the population was exactly 281, 424, 602 million people).

76 Id. at 226. 
gallons were withdrawn per day. ${ }^{77}$ Much of the water for human consumption is groundwater withdrawn from aquifers through wells. ${ }^{78}$ In 2002, the United States was ranked third in the world for countries with extensive over-pumping of aquifers. ${ }^{79}$ Almost half of all irrigation water in the United States comes from underground. Texas, Kansas, and Nebraska receive most of their irrigation water from the Ogallala aquifer, which has little recharge because it is essentially a fossil aquifer. ${ }^{80}$ The underground water table has dropped by 100 feet in parts of Texas, Oklahoma, and Kansas. ${ }^{81}$ Florida's water tables have also dropped because of increases in population. ${ }^{82}$

In the twentieth century, Florida had a great increase in population. ${ }^{83}$ In every decade since the 1920s, Florida has been in the top four states in increases in population. ${ }^{84}$ In the 1980 s, there was a 33 percent increase in population resulting in an increase of 3.2 million people, and in the 1990s, Florida's population increased another twenty percent. ${ }^{85}$ In 2000, Florida had over 15.9 million persons and the Census Bureau predicts Florida will become the nation's third largest state between 2015 and $2020 .^{86}$ The first census of Florida was taken in 1830, and it reported 34,730 persons. By the turn of the century, Florida's population increased over a half a million. ${ }^{87}$ The decades of the 1960s, 1970s, and 1980s were times of exceptional population growth, when nearly one thousand people per day moved into South

$77 \quad I d$.

79 Lester R. Brown, Plan B: Rescuing a Planet Under Stress and a Civilization in Trouble 26 (W.W. Norton \& Co. 2003).

80 Id. at 41 .

81 Id. at 29

82 See id. at 1-26 (stating that humanity's demands on the earth have multiplied over the last halfcentury. As the world's population has doubled, the world's water is facing a deficit. The imminent water deficit usually takes the form of aquifer over-pumping, which is mainly due to increases in population).

83 See FERNALD \& PURDUM, supra note 54, at 81 (stating that Florida's increases in population have ranked highest in the nation).

84 See MORRIS \& MORRIS, supra note 59, at 621(stating that Florida's extraordinary growth since World War II has come from retirees and workers from other states and also from refugees from Cuba, Haiti, and Vietnam); see also FERNALD \& PURDUM, supra note 54, at 6.

85 See MORRIS \& MORRIS, supra note 59, at 621 (stating that the population increase of the 1980s was the largest in Florida's history and second largest in the United States); see also UNIVERSITY OF Florida, Florida Statistical AbSTRact 20066 (Univ. of Florida Bureau of Economics 40th ed. 2006) (percentage changed 23.5 percent between 1990 and 2000).

86 See id.; see also UNIVERSITY OF FlORIDA, FlORIDA STATISTICAL ABSTRACT 20066 (Univ. of Florida Bureau of Economics 40th ed. 2006) (Florida's total population was 15, 982, 378 in 2000).

87 FERNALD \& PURDUM, supra note 54, at 97; UNIVERSITY OF FlORIDA, FlORIDA STATISTICAL ABSTRACT 2006628 (Univ. of Florida Bureau of Economics 40th ed. 2006) (stating that in the year 1990 , the population was 528,542 people). 
Florida. $^{88}$ In 2000, Miami-Dade was the most populous county in Florida with a population of over two million. ${ }^{89}$ With this increase in people came an increase in the demand for water and development, which further destroyed wetlands. ${ }^{90}$ Although population increases are a main reason for the destruction of wetlands, it is not the only reason why many wetlands that once existed do not exist today. Many early federal wetlands regulations also contributed to the loss of wetlands.

\section{Early Wetland Regulations}

The Swamp and Overflow Land Acts of 1849, 1850, and 1860 promoted wetland drainage. Millions of acres of wetlands were transferred from the federal government to the states to reclaim swamplands for agriculture and development. ${ }^{91}$ In 1905, 82 million acres of wetlands had been claimed by fifteen states. ${ }^{2}$ Following these Acts, nearly half of these wetlands were destroyed by drainage projects. ${ }^{93}$ The Swamp and Overflow Land Acts were not the only Acts contributing to the loss of wetlands.

The Flood Control Acts, enacted by Congress between the years 1928 and $1965,{ }^{94}$ resulted in the Army Corps of Engineers spending billions of dollars for the construction of levees, reservoirs, and dams for the purpose of flood control. ${ }^{95}$ The Flood Control Act of 1944 was enacted after severe flooding devastated the lower Missouri River basin and authorized the Army Corps of Engineers to build major projects for draining agricultural

88 John J. Fumero, Environmental Law: 1994 Survey of Florida Law-At A Crossroads In Natural Resource Protection And Management In Florida, 19 NovA L. REV. 77, 78 (1994); see also EDWARD A. Fernald \& Elizabeth D. Purdum, ATlas of Florida, 97 (Univ. Press of Florida 1992) (stating that Florida's population almost doubled between the years of 1960 and 1980).

89 MORRIS \& MORRIS, supra note 59, at 489

90 See VILEISIS, supra note 7, at 7 (eleven million acres of wetlands were transformed into farms, suburbs, shopping centers, and airports between the 1950s and mid 1970s).

91 See TINER, supra note 39, at 110 (all of the Great Lakes received swampland).

$92 I d$. at 113 (northeastern states not included in the Acts because the original thirteen states owned most of the lands).

93 DUGAN, supra note 42 , at 48.

94 See e.g., Flood Control Act of 1936, Pub. L. No. 74-738, 49 Stat. 1570 (codified as amended at 33 U.S.C. § 701(a) (2000)); Flood Control Act of 1944, Pub. L. No. 78-534, 58 Stat. 887 (codified as amended at 33 U.S.C. § 701-1 (2000)); Flood Control Act of 1965, Pub. L. No. 89-298, 79 Stat. 1073 (1965).

95 See Flood Control Act of 1936, Pub. L. No. 74-738, 49 Stat. 1570 (codified as amended at 33 U.S.C. § 701(a) (2000)); Flood Control Act of 1944, Pub. L. No. 78-534, 58 Stat. 887 (codified as amended at 33 U.S.C. § 701-1 (2000)); Flood Control Act of 1965, Pub. L. 89-298, 79 Stat. 1073 (1965). 
lands. ${ }^{96}$ In the process of building levees, reservoirs, and dams to prevent floods, wetlands were destroyed.

Throughout the history of the United States, millions of acres of wetlands were destroyed. Wetlands were destroyed not only because of America's increasing population, which required development and increasing water withdrawals, but also because of early wetland regulations. The Swamp and Overflow Land Acts and the Flood Control Acts both contributed to the loss of wetlands. Unfortunately, the effort to preserve wetlands did not arise until the enactment of the National Environmental Policy Act (NEPA) and the Federal Water Pollution Control Act (FWPCA), which is now called the Clean Water Act (CWA).

\section{WETLAND PRESERVATION}

Wetland preservation started in the 1970s with the enactment of the NEPA. The primary authority, however, for wetland regulation is the CWA. Many other initiatives were taken by the federal government to conserve wetlands, such as President George H. W. Bush's policy of "No Net Loss" of wetlands and also the Emergency Wetlands Resources Act of 1986. Initiatives to preserve wetlands were not only taken by the federal government, but also by state governments. The Florida Constitution and Florida Statutes both provide protection for wetlands. Initiatives to preserve wetlands by the federal government include the NEPA, the CWA, the "No Net Loss Policy" of wetlands, and the Emergency Wetlands Resources Act of 1986.

\section{A. The National Environmental Policy Act}

The NEPA, signed into law by President Nixon in $1970^{98}$, imposes requirements on those seeking permits for activities involving dredging or filling. ${ }^{99}$ It was the first modern federal environmental statute setting forth

96 See South Dakota v. Bourland, 508 U.S. 679 , 683 (1993); see also Flood Control Act of 1944, Pub. L. No. 78-534, 58 Stat. 887 (codified as amended at 33 U.S.C. § 701-1 (2000)).

97 See PerCIVAL, supra note 1, at, 590-92 (The Rivers and Harbors Act of 1899 helped provide the means for the establishment of the Clean Water Act. The Rivers and Harbors Act of 1899 was not to control water pollution, which was largely a local responsibility, but to prevent interferences with navigation. The Act prohibited unpermitted discharges of refuse into navigable waters. The Act later became known as the Refuse Act, and was not considered a pollution control act until the 1960s, when the Supreme Court extended the Act to include industrial wastes even if navigation was in jeopardy. The reinforcement of the Act helped provide the means for establishing the Federal Water Pollution Control Act.).

98 See id. $\S$ 4321-70a.

99 See generally National Environment Policy Act of 1969, 42 U.S.C. $\$ 4321$ (2000). 
broad goals for the nation's environmental policy. ${ }^{100}$ The NEPA required the federal government to use all practicable means and measures to create conditions for man and nature to exist in harmony and "fulfill the social, economic, and other requirements of present and future generations of Americans." ${ }^{101}$ Section 102(2)(C) of the NEPA requires that a federal agency prepare a "detailed statement," known as an "environmental impact statement" (EIS), when it intends to take a major federal action significantly affecting the quality of human environment. ${ }^{102}$ The EIS must identify (1) environmental impacts of the proposed action; (2) adverse environmental effects which cannot be avoided; (3) alternatives to the action; (4) the relationship between short-term uses of man's environment and the maintenance and enhancement of long-term productivity; and (5) any irreversible and irretrievable commitments of resources which would be involved in the proposed action should it be implemented. ${ }^{103}$ In sum, the EIS describes the proposed federal action, discusses environmental impacts, and reports alternatives along with their environmental effects. ${ }^{104}$

Congress also created the Council on Environmental Quality (CEQ) to coordinate each federal agency's compliance with the NEPA. ${ }^{105}$ Section 202 establishes the CEQ, which is created in the executive office of the president and is composed of three members. ${ }^{106}$ The duties and functions of the CEQ include analyzing and interpreting environmental trends, reporting on the conditions of the environment, gathering information, appraising programs and activities of the federal government, and formulating and recommending national policies that promote the improvement of the quality of the environment. ${ }^{107}$

\section{B. The Clean Water Act}

The NEPA is not the only Act that contributes to the preservation of wetlands. The Federal Water Pollution Control Act (FWPCA), now called the Clean Water Act (CWA), is the primary authority for the federal regulation of dredging or filling wetlands. ${ }^{108}$ The Federal Water Pollution Control

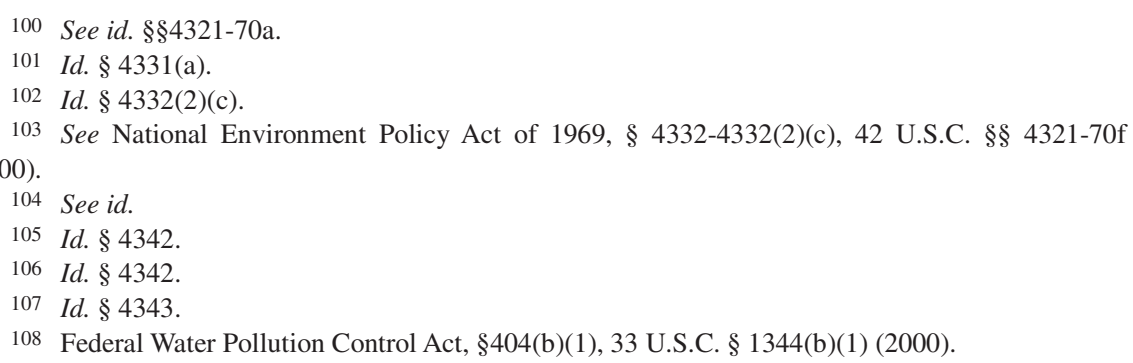


Act of 1972 is the modern federal regulation of water pollution. ${ }^{109}$ The purpose of the FWPCA is to restore and maintain the "chemical, physical, and biological integrity of the Nation's waters." In 1977, the FWCPA was amended and renamed the CWA. ${ }^{111}$ The CWA is the primary law conserving wetlands in the United States. ${ }^{11}$

Section 311 of the CWA prohibits discharges of pollutants into "navigable waters," which is defined as "waters of the United States," unless authorized by permit. ${ }^{113}$ Approximately ninety-eight to ninety-nine percent of the bodies of water in the United States are not navigable, but the quality of navigable waters is greatly affected by non-navigable waters and wetlands adjacent to both navigable and nonnavigable waters. ${ }^{114}$ In United States $v$. Riverside Bayview Homes, Inc., the Supreme Court held that the definition of "waters of the United States" encompasses all wetlands adjacent to other bodies of water. ${ }^{115}$ Section 311 would seem to prevent the filling of most wetlands, but the CWA provides an exception.

Section 404 of the CWA requires a permit for the disposal of dredged or fill material into navigable waters. ${ }^{116}$ The jurisdictional reach of a section 404 permit extends to wetlands. ${ }^{117}$ Section 404 grants authority to the Army Corps of Engineers to issue permits for the disposal of dredged or fill material into wetlands. ${ }^{118}$ The Army Corps of Engineers may issue permits on a state, regional, or national basis for any category of activities involving

109 See PERCIVAL, supra note 1, at 591 (stating that the revived Rivers and Harbors Act of 1899 , also known as the Refuse Act which later prohibited discharges into navigable waters of the United States, was the means for the FWPCA).

110 The Clean Water Act, 33 U.S.C. § 1251(a)(2000).

111 Percival, supra note 1, at , 592 (explaining that the Clean Water Act is not the only federal statute regulating water pollution; the Marine Protection, Research, and Sanctuaries Act, and Coastal Zone Management Acts are others).

112 FREEMAN \& KOLSTAD, supra note 65, at 325.

113 Federal Water Pollution Control Act (Clean Water Act), 33 U.S.C. § 1311(a) (2000). "Pollutant" includes "dredged soil, solid waste, incinerator residue, sewage, garbage, sewage sludge, munitions, chemical wastes, biological materials, radioactive materials, heat, wrecked or discarded equipment, rock, sand, cellar dirt and industrial, municipal, and agricultural waste discharged into water." Federal Water Pollution Control Act (Clean Water Act), 33 U.S.C. § 1362(6) (2000).

114 PerCIVAL, supra note 1, at 599; see also United States v. Riverside Bayview Homes, Inc. 474 U.S. 121, 123 (1985) (stating that under $\$ \$ 301$ and 502 of the Act, depositing dredged or fill materials into navigable waters is forbidden unless authorized by a permit under $\S 404$ ).

115 United States v. Riverside Bayview Homes, Inc. 474 U.S. 121, 131 (1985); see also Ropanos v. United States, 126 S.Ct. 2208, 2225 (2006) (holding that for a wetland to come within the CWA's jurisdiction, it must be a water of the United States defined as being "relatively permanent, standing or continuously flowing," or adjacent to such a water); see also William P. Keith, Recent Developments, 22 J. LAND USE \& ENVTL. L 139, 141 (2006) (stating that adjacency requires "continuous surface connection.").

116 Federal Water Pollution Control Act (Clean Water Act), 33 U.S.C. § 1344(a) (2000).

117 United States v. Riverside Bayview Homes, Inc. 474 U.S. 121 (1985).

118 The Federal Water Pollution Control Act (Clean Water Act), 33 U.S.C. § 1344(a) (2000). 
discharges of dredged or fill material, after public notice and opportunity for public hearings, if "(1) the activities in such category are similar in nature, (2) will cause only minimal adverse environmental effects when performed separately, and (3) will have only minimal cumulative adverse effect on the environment." 119 During the permit process, the Army Corps of Engineers must issue a statement of finding, or a record of decision, if an environmental impact statement was prepared. ${ }^{120}$

The CWA prohibits issuance of a dredge or fill permit if "(1) an environmentally preferable and practicable alternative exists, or (2) the proposed mining activity will cause or contribute to significant degradation of the subject wetlands measured by significantly adverse effects on municipal water supplies, wildlife and wildlife habitat, or aesthetic values, or (3) the potential adverse impacts are not minimized through appropriate and practical steps."

An essential feature to the section 404 permitting process includes measures to mitigate the losses of wetlands by creating new wetlands or improving degraded areas of wetlands. ${ }^{122}$ Mitigation measures are controversial because environmentalists claim the measures make it easy to obtain a section 404 permit when practicable alternatives exist, and also because the benefits of natural wetlands outweigh artificial wetlands, which occasionally fail. $^{123}$

\section{C. "No Net Loss"}

The "No Net Loss" of wetlands, created by President George Bush in 1989, established a national goal that for each acre of wetland destroyed, one acre of wetland must be created. ${ }^{124}$ Four years later, President Clinton reiterated the commitment of no net loss of wetlands during his campaign. ${ }^{125}$ The policy was later reaffirmed in 2002 by President George W. Bush and again in 2004 when he challenged the nation on increasing water

$119 I d$. at $\S 1344(\mathrm{e})$

12033 C.F.R. $\S 325.2(a)(6)$ (2007); see also 40 C.F.R. 230.10(a)(2) (2007) (stating that a practicable alternative is "available and capable of being done after taking into consideration cost, existing technology, and logistics in light of overall project purposes).

121 Sierra Club v. Flowers, 423 F. Supp. 2d 1273, 1351 (S.D. Fla. 2006).

122 See, e.g., National Wildlife Federation v. Whistler, 27 F.3d 1341 (8th Cir. 1994) (upholding issuance of permit due to the mitigation measures that the project would result in little or no net loss of wetlands because the developer agreed to mitigation plan to improve an existing twenty-acre area of wetlands by providing the area with water all year).

123 PERCIVAL, supra note 1 , at 692.

124 DAVIS \& ARSENAUlT, supra note 5, at 130.

125 FREEMAN \& KOLSTAD, supra note 65, at 323. 
quantity and quality. ${ }^{126}$ Under the policy, one must first prevent impacts to wetlands and if the impacts are not avoidable, then one must minimize the impacts through mitigation, which may include restoring degraded wetlands, preserving wetlands, or creating wetlands. ${ }^{127}$

Mitigation activities are falling short of former President Bush's "No Net Loss" of wetlands. The goal, that for every acre of wetlands destroyed one must be created, is not being met. ${ }^{128}$ During the 1970s and 1980s, the Environmental Protection Agency (EPA) and the Corps relied on prescriptive regulation to discourage wetland development. ${ }^{129}$ If a permit under the CWA was granted for the filling or dredging of wetlands, on-site mitigation of destroyed wetlands was required to ensure no net loss. ${ }^{130}$ During the 1990s, agencies and governments favored a market mechanism to ensure no net loss of wetlands. ${ }^{131}$ The market mechanism is known as Wetland Mitigation Banking (WMB). Wetlands are created, restored, or preserved for developers of wetlands to buy as a condition for a permit. ${ }^{132}$ Under the CWA, when applying for a section 404 permit to dredge or fill wetlands, a developer must restore, create, or preserve wetlands to compensate for the existing wetlands destroyed. The Mitigation Banking Review Team (MBRT) approves mitigation banks. ${ }^{133}$ The MBRT establishes conditions of the bank site, performance standards, and conditions for releasing credits. ${ }^{134}$ Once a WMB meets performance standards, credits are produced. One may use the mitigation credits or sell the credits to a developer who needs to satisfy a permit condition. ${ }^{13}$

Many studies have found that mitigation banking is not successful. ${ }^{136}$ Many restored or created wetlands have reverted back to its original habitat because developers planted only what was necessary to meet permit requirements, and then developers left the wetland to revert back to being a

126 Mark Squillace, From "Navigable Waters" To "Constitutional Waters": The Future of Federal Wetlands Regulation, 40 U MiCH. J.L. REFORM 799, 810 (2007).

127 Cynthia Goldberg, Working to Protect and Preserve the Gulf of Mexico, Mar. 7-8, 2002, http://oceancommission.gov/publicomment/gulfcomments/goldberg_comment.pdf (last visited Dec. 6 . 2007); Andrew A. Rosenberg, Regional Governance and Ecosystem-Based Management of Ocean and Coastal Resources: Can We Get There From Here?, 16 Duke EnVTL. L. \& POL'Y F. 179, 182 (2006).

128 Id.

129 FREEMAN \& KOLSTAD, supra note 65, at 324.

130 Id.

131 Id.

132 Id

133 Royal C. Gardner, Perspectives on Wetlands and Biodiversity: International Law, Iraqi Marshlands, and Incentives for Restoration, 2003 COLO. J. INT’L ENVTL. L. \& POL'Y 1, 16 (2003).

134 Id.

135 Id.

136 Id. at 15. 
wetland in name only. ${ }^{137}$ Other problems within WMB include unequal trades of wetlands. Not all wetlands are equal because wetlands differ in the services they deliver, the type, and their location. ${ }^{138}$ The "No Net Loss" of wetlands should include not only the loss of acreage, but also the loss of their functional value. ${ }^{139}$

Distributional equity is another problem with mitigation banking. ${ }^{140}$ Developers create wetlands in rural areas where land is cheap, and they destroy wetlands in urban areas where land is valuable. The existing wetlands in urban areas provide important services to urban populations. The urban populations need the services the wetlands provide, but developers are not creating wetlands in urban areas. Instead, developers create wetlands in rural areas where their services are not needed. ${ }^{141}$ Although the "No Net Loss" of wetlands has received much criticism, mitigation is not the only way to preserve wetlands. Protecting wetlands through acquisition in fee is also a means of wetland preservation. The Emergency Wetlands Resources Act (EWRA) provides for protecting wetlands though acquisition in fee.

\section{Emergency Wetlands Resources Act}

In 1986, Congress passed the Emergency Wetlands Resources Act (EWRA) with the purpose of promoting the conservation of wetlands of the nation to maintain public benefits that wetlands provide and to fulfill international obligations contained in various treaties for migratory birds. ${ }^{142}$ Congress would promote the conservation of wetlands by: "(1) intensifying cooperative efforts among private interests and local, State, and Federal governments; and (2) intensifying efforts to protect the wetlands of the Nation through acquisition in fee, easements or other interests and methods by local, State, and Federal governments and the private sector."143

Congress made numerous findings on the importance of wetlands. ${ }^{144}$ Some of Congress's findings on the importance of wetlands are as follows: (1) wetlands play an important role in maintaining the quality of life by contributing to food supply; water supply and quantity, and flood control; (2) wetlands enhance the water quality and water supply of the nation by

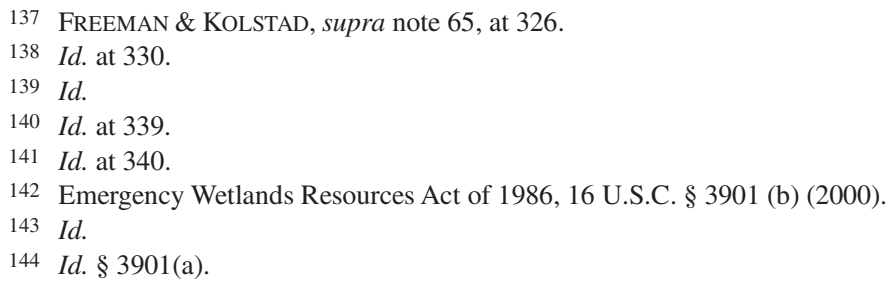


serving as groundwater recharge areas; (3) wetlands provide habitat for migratory birds for breeding, wintering, or migration; and (4) wetlands provide a natural means of flood and erosion control. ${ }^{145}$

The NEPA, the CWA, and the EWRA all contribute to the preservation of wetlands. Despite the criticism that President Bush's "No Net Loss" policy has received for not adequately preserving wetlands, the NEPA and the CWA are effective ways to protect wetlands, but only absent a threat of a takings claim if one is denied a permit to dredge or fill wetlands. The NEPA, the CWA, the "No Net Loss" of wetlands, and the EWRA are not the only efforts to conserve wetlands. State governments have also enacted legislation for the preservation of wetlands. Florida's Constitution and Florida Statutes both provide for wetland preservation.

\section{E. Florida Wetland Preservation}

In Florida, wetland preservation has become the center of attention for environmentalists and legislators. The Florida Legislature and conservationists are struggling to preserve many of Florida's wetlands. The Florida Constitution and Florida Statutes both provide protection for wetlands.

\section{The Florida Constitution}

The Florida Constitution, Article II, Section 7(a) states: "It shall be the policy of the state to conserve and protect its natural resources and scenic beauty. Adequate provision shall be made by law for the abatement of air and water pollution and of excessive and unnecessary noise and for the conservation and protection of natural resources.",

\section{Florida Statutes}

\section{a. The Florida Water Resources Act of 1972}

The Florida Water Resources Act of 1972 (FWRA) provides authority for all Florida water management districts to protect the water resources of the state. ${ }^{147}$ There are five water management districts in Florida. ${ }^{148}$ The five districts include the Northwest Florida Water Management District, the Suwannee River Water Management District, the St. Jones River Water Management District, the Southwest Florida Water Management District,

\footnotetext{
145 Id.

146 FLA. CONST. art. II, § 7, subsec. a.

147 The Florida Water Resources Act, FLA. STAT. § 373 (2008).

148 Id. $\$ 373.069$.
} 
and the South Florida Water Management District. ${ }^{149}$ The entire Everglades ecosystem, from Lake Okeechobee to the Florida Keys, lies within the South Florida Water Management District. ${ }^{150}$ FWRA establishes Florida's jurisdiction over wetlands by defining "wetlands" and "waters of the state." 151 The FWRA is not the only Florida Statute contributing to the preservation of wetlands. The Land Conservation Act of 1972 also contributes to the preservation of wetlands.

\section{b. The Land Conservation Act of 1972}

The Land Conservation Act of 1972 establishes a land acquisition program to conserve and protect lands situated in areas of critical state concern. ${ }^{152}$ Lands situated in areas of critical state concern include:

An area containing, or having a significant impact upon, environmental or natural resources of regional or statewide importance, including, but not limited to, state or federal parks, forests, wildlife refuges, wilderness areas, aquatic preserves, major rivers and estuaries, state environmentally endangered lands, Outstanding Florida Waters, and aquifer recharge areas, the uncontrolled private or public development of which would cause substantial deterioration of such resources. ${ }^{15}$

In addition to the FWRA and the Land Conservation Act of 1972 providing for the preservation of wetlands in Florida, the Warren S. Henderson Wetlands Protection Act of 1984 and the Florida Environmental Reorganization Acts of 1975 and 1993 also provide for the protection of wetlands.

c. The Warren S. Henderson Wetlands Protection Act of 1984 and the Florida Environmental Reorganization Acts of 1975 and 1993

Prior to the Warren S. Henderson Wetlands Protection Act of 1984, the Florida Environmental Reorganization Act of 1975 established a wetland resource permitting program for dredge and fill activities in wetlands covered by Florida Statutes, Chapter 403. ${ }^{154}$ The Chapter 403 wetlands permitting program was later modified in 1984 under the Warren S. Henderson

149 Id.

150 Mary Doyle \& Donald E. Jodrey, Everglades Restoration: Forging New Law in Allocating Water for the Environment, 8 ENVTL. LAW. 255, 267 (2002).

151 FLA. STAT. § 373.

152 FLA. STAT. $\$ 259.045$ (2008).

153 FLA. STAT. $\$ 380.05$ (2008).

154 FLA. STAT. $\$ 403$ (2008); see also Weston Wheeler, Federalism of Florida Wetlands Protection. ENVTL. AND LAND USE LAW SECTION OF THE FLORIDA BAR, Feb. 2001, http://www.eluls.org/reporter_fe b2001/feb2001_wheeler.html. 
Wetlands Protection Act. ${ }^{155}$ In 1993, the Florida Legislature enacted the Florida Environmental Reorganization Act (FERA). ${ }^{156}$ FERA integrated the Chapter 403 wetlands resource permits into Chapter 373, "Management and Storage of Surface Waters," with the objective to create a unified state permitting process, which is known as the Environmental Resource Permit (ERP) program. ${ }^{157}$ FERA also merged the Department of Environmental Regulation and Natural Resources into a newly created agency: the Department of Environmental Protection (DEP). ${ }^{15}$

Under FERA, an applicant for a permit to conduct activities in surface waters and wetlands must provide reasonable assurance that state water quality standards will not be violated, and an applicant must provide reasonable assurance that activity in, on, or over surface waters or wetlands is not contrary to the public interest. ${ }^{159}$ In determining whether an activity is contrary to the public interest, the following criteria are considered:

1. Whether the activity will adversely affect the public health, safety, or welfare or the property of others; 2 . Whether the activity will adversely affect the conservation of fish and wildlife, including endangered or threatened species, or their habitats; 3 . Whether the activity will adversely affect navigation or the flow of water or cause harmful erosion or shoaling; 4 . Whether the activity will adversely affect the fishing or recreational values or marine productivity in the vicinity of the activity; 5 . Whether the activity will be of a temporary or permanent nature; 6 . Whether the activity will adversely affect or will enhance significant historical and archaeological resources under the provisions of s. 267.061; and 7. The current condition and relative value of functions being performed by areas affected by the proposed activity.

If an applicant is unable to meet the above criteria, the governing department must consider measures to mitigate adverse effects when deciding

155 FLA. STAT. §§ 403.91-.929; see also Weston Wheeler, Federalism of Florida Wetlands Protection. ENVTL. AND LAND USE LAW SECTION OF THE FLORIDA BAR, Feb. 2001, http://www.eluls.org/repor ter_feb2001/feb2001_wheeler.html.

156 FLA. STAT. § 373; see also Weston Wheeler, Federalism of Florida Wetlands Protection. ENVTL. AND LAND USE LAW SECTION OF THE FLORIDA BAR, Feb. 2001, http://www.eluls.org/reporter_fe b2001/feb2001_wheeler.html.

157 Weston Wheeler, Federalism of Florida Wetlands Protection. ENVTL. AND LAND USE LAW SECTION OF THE FLORIDA BAR, Feb. 2001, http://www.eluls.org/reporter_feb2001/feb2001_wheeler.htm 1.

158 Id.

159 FLA. STAT. $\$ 373.414$.

160 Id. 
to grant or deny a permit. ${ }^{161}$ Measures to mitigate adverse effects caused by the activity may include onsite mitigation, offsite mitigation, and the purchase of mitigation credits. ${ }^{162}$ The mitigation must offset the adverse effects caused by the activity. ${ }^{163}$ Although mitigation was an attractive solution to conserving wetlands, it was not the only solution. Seven years after the FERA was enacted, the Florida Legislature enacted the Florida Preservation 2000 Act to further preserve wetlands.

\section{d. Florida Preservation 2000 Act}

The Florida Preservation 2000 Act creates a funding mechanism for land acquisition programs in Florida to protect the integrity of ecological systems. $^{164}$ The Legislature found that the development of Florida's natural areas to accommodate rapid population growth contributed to the degradation of water resources, destruction of wildlife habitats, and the diminishment of wetlands. ${ }^{165}$ The Legislature also found that South Florida's water supply depends on the protection of lands buffering the East Everglades and the Everglades water conservation areas. ${ }^{166}$ Development of natural areas created a need for public land acquisition to preserve the quality of life in Florida. $^{167}$ The Legislature recognized the urgency of acquiring natural areas for preservation and declared its intent to fund the implementation of the Florida Preservation 2000 Act for each of the 10 years of the program's duration. ${ }^{168}$

The Florida Constitution and Florida Statutes both contribute to wetland preservation. The importance of the preservation of wetlands is not only a federal goal, but it is also a state goal. The FWRA, the Land Conservation Act, the FERA, and the Florida Preservation 2000 Act all provide for the conservation of wetlands. Wetland preservation is not only the center of attention at federal and state levels but also at the international level.

\section{e. International Wetland Protection}

The Ramsar Convention, known as the Convention on Wetlands, is the first modern environmental treaty on the conservation and sustainable use

\footnotetext{
161 Id.

162 Id.

163 Id.

164 FLA. STAT. § 259.101 (2008).

165 FlA. STAT. § 259.101(2)(a) (2008).

166 FLA. STAT. $\$ 259.101$ (2)(e) (2008).

167 FLA. STAT. § 259.101(2)(b) (2008).

168 FLA. STAT. § 259.101(2) (2008).
} 
of natural resources. ${ }^{169}$ The Convention on Wetlands was signed in Ramsar, Iran, in 1971, and it presently consists of 158 parties. ${ }^{170}$ The Ramsar Convention imposes obligations on parties to designate at least one wetland site within its territory as a wetland of international importance. ${ }^{171}$ There are presently 1,718 designated wetland sites in the Ramsar Convention. ${ }^{172}$ Identifying wetlands of international importance is based on the type of the wetland, the presence of endangered species, and the site's support of waterbirds and fish. ${ }^{173}$ The parties should conserve the wetlands that are designated wetlands of international importance and should wisely use other wetlands. ${ }^{174}$ The Convention's mission statement is "the conservation and wise use of all wetlands through local, regional and national actions and international cooperation, as a contribution towards achieving sustainable development throughout the world."175

The NEPA, the CWA, the "No Net Loss" of wetlands, and the EWRA represent the initiatives taken by the federal government to preserve wetlands. The NEPA places requirements on those seeking permits for activities involving dredging or filling. Those who seek to develop wetlands need a Section 404 permit from the Corps under the CWA. The NEPA requires the Corps to follow certain procedures before issuing a permit for dredging or filling wetlands. The NEPA and the CWA both contribute to the preservation of wetlands by requiring both developers and the Corps to meet certain criteria before a permit is issued for dredging or filling a wetland. There were not only federal initiatives to preserve wetlands, but also state initiatives.

Florida enacted the FWRA of 1972, the Land Conservation Act of 1972, the FERA of 1975, the Warren S. Henderson Wetlands Protection Act of 1984, and the FERA of 1993. All of the Florida Statutes provided measures for the protection of wetlands. The Florida Statutes protected wetlands by requiring a permit to dredge or fill wetlands. The Florida Statutes also conserved wetlands by providing for acquisition of wetlands or mitigation. Wetland preservation has become the center of attention not only at state and national levels, but also at the international level through the Ramsar Convention.

169 Royal C. Gardner, Perspectives on Wetlands and Biodiversity: International law, Iraqi Marshlands, and Incentives for Restoration, 2003 COLO. J. INT'L ENVTL. L. \& POL'Y 1, 2 (2003).

170 The Ramsar Convention on Wetlands, http://www.ramsar.org (last visited Feb. 12, 2008).

171 Id.

172 Id.

$173 I d$.

174 Id.

175 Id. 
Despite the growing awareness of the importance of wetlands and the many efforts to protect wetlands at the national, state, and international levels, wetlands are still threatened. Developers continue to seek permits under the CWA, and the Army Corps of Engineers continue to grant the permits. Requiring permits under the CWA at the federal level and under the FERA of 1993 at the state level in Florida is an effective way to protect wetlands, but only if there is not the threat of a takings claim if a private property owner is denied a permit.

\section{THE PROBLEM - REGULATORY TAKINGS}

Public awareness of the importance of wetlands and the consequences of their destruction led to significant governmental regulations to protect wetlands, but private property owners can threaten the effectiveness of the regulations by claiming an unconstitutional taking. When private property owners are required to obtain permits to develop wetlands, but are denied permits by the regulatory agency in charge of granting the permit, developers challenge the permit denials by claiming a regulatory taking. This creates a problem between conserving wetlands and private property rights. This problem was apparent in Sierra Club v. Flowers and Sierra Club v. Strock, when the Army Corps of Engineers issued a permit to a mining company without performing the requirements in the NEPA and the CWA. ${ }^{176}$ The Army Corps of Engineers was reminded of an earlier case, Florida Rock Industries v. United States, when the Army Corps of Engineers denied a permit, and the denial was challenged as a regulatory taking. ${ }^{177}$ Florida Rock Industries eventually settled for \$21 million dollars. ${ }^{178}$ The CWA and many other legislative enactments that are intended to protect wetlands are not an effective means of preserving wetlands if regulatory agencies are threatened with takings claims. Agencies will negotiate with developers instead of serving as regulatory agencies. An example of this situation can be seen in Sierra Club v. Strock.

\section{A. Sierra Club v. Strock}

In 2007 the Southern District of Florida, in Sierra Club v. Strock, was presented with the question of what further relief should be granted to plaintiffs in light of the conclusions in Sierra Club v. Flowers that the de-

176 Sierra Club v. Strock, 495 F. Supp. 2d 1188 (S.D. Fla. 2007); Sierra Club v. Flowers, 423 F. Supp. 2d 1273 (S.D. Fla. 2006), order supplemented by Sierra Club v. Strock, 495 F. Supp. 2d 188 (S.D. Fla. 2007), vacated by Sierra Club v. Van Antwerp, 526 F.3d 1353 (11th Cir. 2008).

177 Florida Rock Indus., Inc. v. United States, 45 Fed. Cl. 21 (1999).

178 See id. at 44. 
fendants, the Army Corps of Engineers and the United States Fish and Wildlife Service (FWS), committed multiple violations of numerous Acts including the CWA and the NEPA. ${ }^{179}$ In Sierra Club v. Flowers, the United States District Court for the Southern District of Florida ruled in favor of environmental plaintiffs and against the Corps, the FWS, and several private mining companies. ${ }^{180}$ The plaintiffs challenged the Army Corps of Engineers' issuance and extension of dredge and fill permits allowing limestone mining on wetlands. ${ }^{181}$ The violations occurred in relation to the issuance of the CWA, Section 404(b), permits in April 2002 to nine private corporations for the destruction of approximately fifty-four hundred acres of wetlands in Miami, Florida, to remove the underlying limestone for processing into cement, concrete blocks, and other products. ${ }^{182}$

The Court's order granting summary judgment for plaintiffs in Sierra Club v. Flowers concluded the permits should not have been issued because the Army Corps of Engineers and FWS made numerous decisions lacking a rational basis, and they failed to consider all relevant factors in the permitting decision. ${ }^{183}$ The court found the Army Corps of Engineers violated the NEPA by approving mining in close proximity to a wellfield before the risk of contamination had been adequately studied. ${ }^{184}$ The mining was approved in close proximity to the Northwest Wellfield and its multiple wellheads from which drinking water is pumped daily. The Army Corps of Engineers also violated the NEPA requirement that all indirect effects be addressed by dismissing negative impacts of increasing urbanization when preparing the EIS. ${ }^{185}$ The Army Corps of Engineers violated the CWA by not complying with public participation requirements. ${ }^{186}$

In Sierra Club v. Strock, Judge Hoeveler, in deciding what relief should be granted, held that the section 404 permits would be properly set aside to members of the limestone mining industry to conduct mining in water conservation areas pursuant to the NEPA and the CWA. ${ }^{187}$ Keeping limestone products available for purchase and collecting funds from mining companies to be used to acquire wetland restoration did not outweigh the risk of wellfield contamination, destruction of wetlands, and potentially

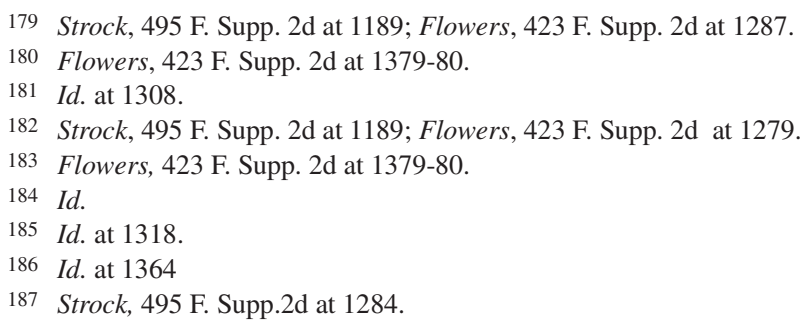


damaging seepage impacts. ${ }^{188}$ Conducting mining in water conservation areas could also contaminate millions of gallons of drinking water drawn daily from the Biscayne Aquifer in Miami, Florida. ${ }^{189}$

The court suggested that the Army Corps of Engineers negotiated with the developers instead of serving as a regulatory agency. ${ }^{190}$ Judge Hoeveler also questioned what role the threat of a taking played in the permitting decision and recognized the likelihood that procedural safeguards in the CWA and other Acts were overlooked because of the threat of takings litigation. ${ }^{191}$ The threat of the mining companies challenging the denial of a permit as a taking was apparent because of the decision in Florida Rock Industries $v$. United States, in which the government settled a takings challenge for \$21 million in 2001. ${ }^{192}$

\section{B. Florida Rock Industries v. United States}

In Florida Rock Industries v. United States, a mining company purchased a parcel of land and, pursuant to the subsequent enactment of the CWA Amendments of 1972, applied for a permit. ${ }^{193}$ The Army Corps of Engineers denied Florida Rock's application for a mining permit to mine ninety-eight acres of wetlands. ${ }^{194}$ Florida Rock later filed a suit, seeking just compensation for a regulatory taking. ${ }^{195}$ Florida Rock initially won in the Federal Court of Claims, and its claim survived several appeals and remands. $^{196}$ The initial award in the claims court was for $\$ 1,029,000$. $^{197}$ Florida Rock later expanded its claim to the entire 1,560 wetland acres it owned, and it was awarded \$10.5 million. ${ }^{198}$ Florida Rock eventually settled the case in 2001 for $\$ 21$ million. ${ }^{199}$

The problem that the Army Corps of Engineers has between satisfying developers of private property and environmentalists, apparent in Florida Rock Industries v. United States and Sierra Club v. Flowers, will continue to reappear. Private property owners will continue to challenge permit denials by claiming the denial constituted a regulatory taking. There are two

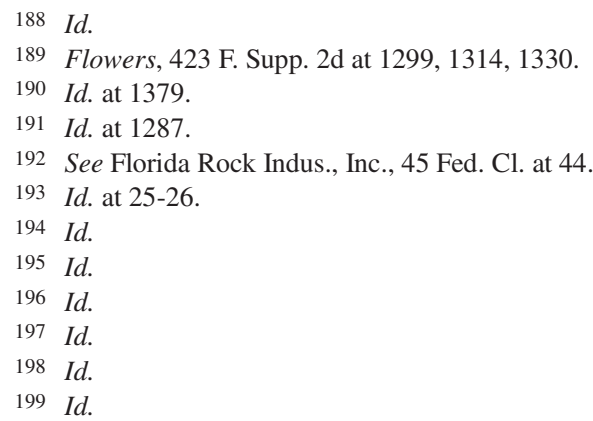


tests to determine whether a regulatory taking exists: the per se regulatory taking test and the ad hoc test.

C. Takings

1. Per Se Regulatory Takings and the Ad Hoc Test

The Fifth Amendment to the United States Constitution states private property shall not be taken for public use without just compensation. ${ }^{200}$ The government may take private property without consent as long as the taking is for public use, and the owner is given just compensation. The Takings Clause involves the police power and the eminent domain power. ${ }^{201}$ When an exercise of the police power exceeds its limits and infringes on private property without adequate public justification, the owner must be compensated for the loss of his property rights. ${ }^{202}$ The Takings Clause serves "to bar Government from forcing some people alone to bear public burdens which, in all fairness and justice, should be borne by the public as a whole." $" 203$

A per se regulatory taking in violation of the Fifth Amendment may be found when regulations completely deprive an owner of all economically viable use of her property unless background principles of nuisance and property law independently restrict the owner's intended use of the property or when government mandates permanent physical invasions of property. ${ }^{204}$ Per se takings require compensation no matter how significant the public interest is in the regulation. ${ }^{205}$

Categorical rules endorse distinct classifications of takings and are characteristics of the nineteenth century legal thinking. ${ }^{206}$ In the twentieth century, courts focused on balancing tests instead of categorical distinctions to determine when a regulatory taking existed. ${ }^{207}$ In 1978 the Supreme Court said it "has been unable to develop any 'set formula' for determining when 'justice and fairness' require that economic injuries caused by public action can be compensated by government, rather than remain disproportio-

200 U.S. CONST. amend. V.

201 GREgORY S. AleXANDER ET AL., Property 955 (Little Brown \& Co. 2006).

202 Id.

203 Armstrong v. United States, 364 U.S. 40, 49 (1960).

204 Lucas v. S.C. Coastal Council, 505 U.S. 1003, (1992); Loretto v. Teleprompter Manhattan CATV Corp., 458 U.S. 419, (1982).

205 ALEXANDER ET AL., supra note 201, at 956.

206 Michael C. Blumm \& Lucus Ritchie, Lucas's Unlikely Legacy: The Rise of Background Principles as Categorical Takings Defenses, 29 HARV. ENVTL. L. REV. 321, 323 (2005).

207 Id. 
nately concentrated on a few persons." 208 To apply the ultimate test of "justice and fairness," the Court engaged in an ad hoc factual inquiry focusing on the following: (1) the "character of the government action," (2) the protection of "reasonable, investment-backed expectations," and (3) the "economic impact" of the regulation on the particular owner. ${ }^{209}$ This ad hoc test assumes owners have obligations as well as rights and also weighs private and public interests. ${ }^{210}$

The per se regulatory test and the ad hoc test are two ways to find whether a taking exists. Under the per se regulatory test, a regulatory taking will be found in only two instances. A taking will be found anytime there is a permanent physical invasion of private property or if an owner is deprived all economically viable use of her property unless background principles of nuisance and property law existed. Under the ad hoc test, the court uses a balancing test, not distinct classifications. While a private property owner can assert a takings claim, the government can also assert a takings defense against the claim.

\section{Categorical Taking Defenses}

In Lucas v. South Carolina Coastal Council, David Lucas purchased two coastal lots with the intent to build homes on each lot. ${ }^{21}$ Two years after he purchased the lots, South Carolina enacted the Beachfront Management Act with the objective of preventing public harm as a result of beach erosion. $^{212}$ The Beachfront Management Act precluded Lucas from building homes on each lot. ${ }^{213}$ Lucas filed suit against the state agency in charge of implementing the Beachfront Management Act claiming a constitutional taking. ${ }^{214}$ In 1992 the United States Supreme Court reversed the South Carolina Supreme Court's decision in finding no taking. ${ }^{215}$ The Court stated that South Carolina needed to "do more than proffer . . . the conclusory assertion that the prohibited uses violate a common law maxim such as sic utere tuo ut alienum non laedas (use what is yours so as not to harm what is others).,"216 Instead, to restrain Lucas in a common law action for public nuisance, "South Carolina must identify background principles of nuisance and property law that prohibit the uses he now intends in the cir-

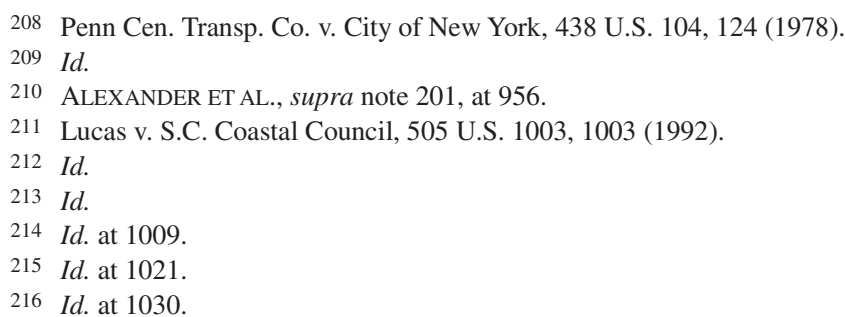


cumstances in which the property is presently found. The government must identify background principles of nuisance and property law.",217

Justice Scalia created a new per se rule expanding categorical takings. ${ }^{218}$ Compensation is required for all regulations that deny "all economically beneficial or productive use of land" unless background principles of property or nuisance restricted the use of a claimant's property at the time of the purchase. ${ }^{219}$ Justice Scalia further stated that:

Any limitation so severe cannot be newly legislated or decreed, but must inhere in the title itself, in the restrictions that background principles of property and nuisance already places upon land ownership. A law or decree with such an effect must, in other words do no more than duplicate the result that could have been achieved in the courts by adjacent landowners (or other uniquely affected persons) under the State's law of private nuisance, or by the State under its complementary power to abate nuisances that affect the public generally, or otherwise. $^{220}$

Lucas characterized nuisances as harms "to public lands and resources, or adjacent private property, posed by the claimant's proposed activities." Although this exception seemed to focus on a nuisance exception only under common law, many courts now view the exception to include aspects of statutory law as a pre-existing limitation on an owner's title, such as a permanent easement. ${ }^{222}$ Compensation may be resisted, even when regulations deprive owners of all economically beneficial use of their land, if the owner's proscribed use interests were not part of the owner's title at the time of purchase. $^{223}$

217 Id. at $1031-32$.

218 Id.; Blumm \& Ritchie, supra note 206, at 324.

219 Lucas, 505 U.S. at 1026-29.

220 Id.

221 Id. at 1030-31.

222 Patty Gerstenblith, Protection of Cultural Heritage Found on Private Land: The Paradigm of Miami Circle and Regulatory Takings Doctrine After Lucas, 13 ST. THOMAS L. REV. 65, 95 (2000) ("[W]e assuredly would permit the government to assert a permanent easement that was a pre-existing limitation upon the landowner's title." (quoting Lucas, 505 U.S. at 1028-29.)); see also Blumm \& Ritchie, supra note 206, at 354 (nothing that, although Justice Scalia cautioned against employing legislatively decreed background principles, many post-Lucas courts sided with Justice Kenney to hold that state and federal statutes may function as a bar to takings challenges).

223 See Lucas, 505 U.S. at 1027; see also Glenn P. Sugameli, Lucas v. South Carolina Coastal Council: The Categorical and Other "Exceptions" to Liability for Fifth Amendment Takings of Private Property Far Outweigh the "Rule," 29 ENVTL. L. 939, 957 (1999) (stating that under Lucas, if a property restriction replicates restrictions inherent in the title to property defined by state and federal property, nuisance law, and the emergency exception, the restriction never effects a taking); see also Blumm \& Ritchie, supra note 206, at 322-27 (stating that Lucas sets forth a requirement that owners must first establish that their property interest is unrestrained by prior restrictions. If the use was not acquired 
In his concurring opinion, Justice Kennedy disagreed with Justice Scalia that background principles cannot be newly legislated or decreed; instead, states should not be prevented from enacting new regulatory initiatives in response to changing conditions. ${ }^{224}$ Justice Kennedy articulated the need to expand background principles further than the common law because "[t]he common law of nuisance is too narrow a confine for the exercise of regulatory power in a complex and interdependent society."225 Many lower courts follow Justice Kennedy's concurrence that background principles include not only common law but also state statutes. ${ }^{226}$

Lucas extended categorical takings liability by creating a new per se rule requiring compensation for all regulations that deny "all economically beneficial or productive use of land."227 Before Lucas, categorical takings were limited to only permanent physical occupations. ${ }^{228}$ In Loretto v. Teleprompter Manhattan CATV Corp., the Court held a minor but permanent physical occupation of cable installation in an apartment building constituted a taking. ${ }^{229}$ In Pruneyard Shopping Center v. Robins, Justice Rehnquist held a privately owned shopping center required to permit visitors for publicly expressive activity and not commercial purposes did not constitute a taking. ${ }^{230}$ The state authorized limitation of the right to exclude others did not unreasonably impair the value or use of the owner's property as a shopping center. ${ }^{231}$

An important aspect of the decision in Lucas was not extending categorical takings liability by creating a new per se rule, but by creating nu-

when the owner purchased the property, which means that it was not one of the sticks in the bundle of rights, then the takings claim must be rejected).

224 Lucas, 505 U.S. at 1032-37 (Kennedy, J., concurring).

225 See id. at 1035 (Kennedy, J., concurring); see also Sugameli, supra note 223, at 943 (articulating the need to expand background principles beyond common law).

226 See, e.g., Hunziker v. Iowa, 519 N.W.2d 367, 370-71 (Iowa 1994) (holding a preexisting Iowa statute as a background principle in Lucas); City of Virginia Beach v. Bell, 498 S.E.2d 414, 417-18 (Va. 1998) (holding claimants never possessed a property right to develop their land because they acquired title after the passage of a law requiring a permit to alter areas on their land). See also Blumm \& Ritchie, supra note 207 , at 334 .

227 Lucas, 505 U.S. at 1015.

228 See id. at 1015-16; see also Loretto v. Teleprompter Manhattan CATV Corp., 458 U.S. 419, 434-35 (1982) (determining that an ordinance requiring the installation of cable television boxes in apartment buildings worked a categorical taking and distinguishing limited property restrictions from permanent physical occupations: "[W] hen the 'character of the government action'. . . is a permanent physical occupation of property, our cases uniformly have found a taking to the extent of the occupation, without regard to whether the action achieves an important public benefit or has only minimal economic impact on the owner."); Blumm \& Ritchie, supra note 206, at 324.

229 Loretto, 458 U.S. 419, 456 (1982).

230 Pruneyard Shopping Cent. v. Robins, 447 U.S. 74, 74 (1980).

231 Id. at 83 . 
merous categorical defenses to defeat takings claims. ${ }^{232}$ The categorical defenses are background principles of nuisance or property law. ${ }^{233} \mathrm{Com}-$ pensation is not required for regulations that deny all economically beneficial or productive use of land if background principles of nuisance or property law restricted the use of a claimant's property at the time of purchase. ${ }^{234}$ Although Lucas extended categorical takings liability, instead of increasing the probability of compensation, Lucas's exceptions created numerous categorical defenses in which government defendants could defeat takings claims. $^{235}$ Categorical defenses include background principles of nuisance and property law. ${ }^{236}$

\section{a. Background Principles of Nuisance}

A public nuisance is an unreasonable interference with a right common to the general public. ${ }^{237}$ Situations involving an unreasonable interference with a pubic right may include behavior that causes a significant "interference with the public health, the public safety, the public peace, the public comfort or the public convenience," or conduct that "is proscribed by a statute, ordinance or administrative regulation.,"238 In Lucas, Justice Scalia ruled background principles consist of both private and public nuisances and that courts should refer to the Restatement (Second) of Torts in determining what constitutes a nuisance. ${ }^{239}$ Lower courts were instructed to analyze the following:

[T] he degree of harm to public lands and resources, or adjacent private property, posed by the claimant's proposed activities, the social value of the claimant's activities and their suitability to the locality in question, and the relative ease with which the alleged harm can be avoided through measures taken by the claimant and the government (or adjacent landowner) alike. ${ }^{240}$

In Sierra Club v. Flowers, denial of a Section 404 permit under the CWA would not constitute a taking because the approved mining was in

232 See Lucas, 505 U.S. at 1067.

233 Id. at 1052.

234 Id. at $1026-29$.

235 See Blumm \& Ritchie, supra note 206, at 321-32 (stating that Lucas's legacy is an example of the law of unintended consequences).

236 Id. at 322.

237 See RESTATEMENT (SECOND) OF TORTS $\$ 821 \mathrm{~B}$ (2009).

238 RESTATEMENT (SECOND) OF TORTS § 821B(2) (2009).

239 See Lucas, 505 U.S. at 1025-31; see also Blumm \& Ritchie, supra note 206, at 334.

240 Lucas, 505 U.S. at 1030-31. 
close proximity to a wellfield from which drinking water is pumped daily. ${ }^{241}$ Contamination in the drinking water was found where mining occurred pursuant to the challenged permits. ${ }^{242}$ Mining in close proximity to the wellfield is an unreasonable interference with the general public's water. ${ }^{243}$ The mining is causing contaminated water, which is a significant interference with public health. ${ }^{244}$ The denial of a permit would not constitute a taking because the mining is creating a nuisance. ${ }^{245}$ The nuisance would qualify as a categorical defense under Lucas. ${ }^{246}$

Under Lucas, developing wetlands that are critical to water resources and essential for public drinking would constitute a nuisance. ${ }^{247}$ Lucas advised lower courts to refer to the Restatement of Torts. ${ }^{248}$ Under the Restatement of Torts, developing wetlands that are critical to water resources would constitute a nuisance. ${ }^{249}$ Developing wetlands that are critical to water resources creates a significant degree of harm to public resources because of contamination, and the value of clean water is greater than the social value of developing wetlands. ${ }^{250}$

Although Lucas recognized that background principles of nuisance could defeat a takings claim, many years prior to Lucas, the Supreme Court had already recognized a nuisance exception. ${ }^{251}$ The Supreme Court applied a nuisance defense to a takings claim in both Mugler v. Kansas and Keystone Bituminous Coal Association v. DeBenedictis. ${ }^{252}$

In Mugler v. Kansas, the Court rejected a takings challenge to a state ban on the manufacture and sale of alcohol because the purpose of the legislation was to avoid injuries to health, morals, or safety of the communi-

241 Sierra Club v. Flowers, 423 F. Supp. 2d 1273, 1313 (S.D. Fla. 2006)

242 Id. at $1315-17$.

243 Id. at 1314.

244 Id. at 1333.

245 See, e.g., id. at $1379-81$.

246 Compare Lucas v. S.C. Coastal Council, 505 U.S. 1003, 1029-32 (1992) (spawning the rise of categorical defenses to takings claims), with Blumm \& Ritchie, supra note 207, at 322-23 (annotating Lucas's categorical defenses to takings claims).

247 Flowers, 423 F. Supp. 2d at 1335-37.

248 Lucas, 505 U.S. at 1025-30.

249 Compare Lucas, 505 U.S. at 1030-31, with RESTATEMENT (SECOND) OF TORTS $§ 826$ (2009).

250 See generally Blumm \& Ritchie, supra note 206, at 336-38 (arguing that healthy wetlands are valuable resources that prevent public harms by maintaining water supply and quality).

251 Compare Lucas, 505 U.S. at 1029-32 (finding background principles of nuisance can defeat takings claims), and Blumm \& Ritchie, supra note 207, at 324 (highlighting background principles of nuisance established in Lucas and the applicability of nuisance principles in defeating takings claims), with Mugler v. Kansas, 123 U.S. 623 (1887) (holding nuisance law an exception to takings claims requiring just compensation).

252 See Mugler, 123 U.S. 623 (1887); see also Keystone Bituminous Coal Ass'n v. DeBenedictis, 480 U.S. 470 (1987). 
ty. $^{253}$ Not only did the nuisance exception apply to common law nuisances, but also statutorily declared nuisances. Many years later, the Supreme Court once again denied a takings challenge to a state statute that prevented individuals from using their property to create a nuisance by applying a traditional nuisance exception.

In Keystone Bituminous Coal Association v. DeBenedictis, a Pennsylvania statute required mining companies of coal to leave fifty percent of coal beneath the surface of land for the support of buildings. ${ }^{255}$ The $\mathrm{Su}-$ preme Court held the statute did not constitute a taking, even though twenty-seven million tons of coal was required to be left in place, depriving the mining company of all value of its subsurface mineral rights estate. ${ }^{256}$ The Court concluded, "no individual has a right to use his property to create a nuisance or otherwise harm others." Key7 Keystone protected regulations designed to prevent serious harm from takings liability. ${ }^{258}$ The majority in Keystone recognized that coal mining that caused the destruction of structures due to the subsidence of surface land was a nuisance, which the law could legitimately prevent by stopping the property owners from causing harm to others and the public at large. ${ }^{259}$

The CWA prohibits issuance of dredge and fill permits of wetlands if the proposed mining activity will cause or contribute to significant degradation of the subject wetlands, measured by significantly adverse effects on municipal water supplies. ${ }^{260}$ Under the FERA, an applicant for a permit to conduct activities in wetlands must provide reasonable assurance that state water quality standards will not be violated. ${ }^{261}$ If an individual is denied a permit under the CWA or the FERA because development will adversely affect municipal water supplies, the denial would not constitute a taking under Keystone. $^{262}$ Similar to Keystone, the denial of the permit under the

253 Mugler, 123 U.S. at 668; see also Blumm \& Ritchie, supra note 206, at 324 (stating that Mugler established a categorical bar to takings liability when the regulation is aimed to eliminate a nuisance).

254 See Keystone., 480 U.S. 470 (1987); see also Blumm \& Ritchie, supra note 206, at 331 (stating that Keystone established arguably the broadest articulation of the traditional nuisance exception).

255 Keystone, 480 U.S. at 478-79.

256 Id. at 491.

257 Id.

258 Blumm \& Ritchie, supra note 206, at 331 (stating that regulations designed to prevent public harms were immune from the $5^{\text {th }}$ Amendment liability in Keystone).

259 Keystone, 480 U.S. at 492-93.

260 Sierra Club v. Flowers, 423 F. Supp. 2d 1273, 1349-51 (S.D. Fla. 2006).

261 FLA. STAT. § 373.414(1) (2008).

262 Compare 33 U.S.C. § 1344(c) (2008), and Flowers, 423 F. Supp. 2d at 1350, with Keystone, 480 U.S. at 492-93. 
CWA would prevent individuals from using their property to create a nuisance and harm others. ${ }^{263}$

Unfortunately, Lucas seemed to deny the concept found in Keystonethat harm preventing regulations are immune from takings liability-when Lucas stated that South Carolina needed to "do more than proffer . . . the conclusory assertion that the prohibited uses violate a common law maxim such as sic utere tuo ut alienum non laedas (use what is yours so as not to harm what is others)., ${ }^{264}$ Instead, the government must identify background principles of nuisance based on "relevant precedents." 265 To defeat a takings claim, the government can identify not only background principles of nuisance based on relevant precedents, but also background principles of property law. ${ }^{266}$

\section{b. Background Principles of Property Law}

Lucas established that background principles of property law inherent in the owner's title at the time of purchase can also defeat a takings claim. ${ }^{267}$ The public trust doctrine, natural use doctrine, navigational servitude, customary rights, and water rights are a few examples of background principles of property law that can be used to defeat a takings claim. ${ }^{268}$ The public trust doctrine is the principle that government is required to protect and maintain certain resources for the public's reasonable use. ${ }^{269}$ The leading case involving the application of the natural use limitation is Just v. Marinette County. ${ }^{270}$ The court in that case held "[a]n owner of land has no absolute and unlimited right to change the essential natural character of his land so as to use it for a purpose for which it was unsuited in its natural

263 Compare 33 U.S.C. $\$ 1344(c)$ (2008), with Keystone, 480 U.S. at 492-93.

264 Lucas v. S.C. Coastal Council, 505 U.S. 1003, 1031 (1992); see also Blumm \& Ritchie, supra note 206, at 332 (stating that Lucas rejected the notion "use what is yours so as not to harm what is others" established in Keystone).

265 Lucas, 505 U.S. at 1032; see, e.g., Blumm \& Ritchie, supra note 206, at 334 (noting that Lucas established the threshold analysis must be based on "relevant precedents"); see also Hendler v. United States, 952 F.2d 1364, 1380-81 (Fed. Cir. 1991) (finding that state statutes may also help define the boundaries of common law concerning nuisances such as here the court held the installation of monitoring wells did not constitute a taking because the contamination was a public nuisance under California's code provisions).

266 See Blumm \& Ritchie, supra note 206, at 341-44 (finding background principles of property law have proven to be much more numerous than takings defenses grounded on nuisance, perhaps because the property rules are not as contextual as nuisance law).

267 See Blumm \& Ritchie, supra note 206, at 344 (finding the natural use doctrine rationale as part of the background principles of property law).

268 Id. at 341-44.

269 Id.

270 See, e.g., Just v. Marinette County, 201 N.W.2d 761 (Wis. 1972). 
state and which injures the rights of others." ${ }^{271}$ Tahoe-Sierra Preservation Council, Inc. v. Tahoe Regional Planning Agency is a case that helps identify the aforementioned background principles of property law that can be used to defeat takings claims. ${ }^{272}$

In Tahoe-Sierra Preservation Council, the Tahoe Regional Planning Agency placed a temporary suspension on construction around Lake Tahoe for six years to avoid the loss of Lake Tahoe's clarity. ${ }^{273}$ Landowners around the lake claimed the temporary suspension took all economically viable use of their property and amounted to a categorical taking under $\mathrm{Lu}$ cas. $^{274}$ The Court clarified that Lucas meant a diminution in the value of property must be a complete elimination of value-that is, a 100 percent diminution-and held it was not a per se taking of property. ${ }^{275}$

Chief Justice Rehnquist dissented, reasoning that such a long moratorium was not related to background principles of property law. ${ }^{276}$ Instead, regulations that are background principles of property law constitute zoning and permit regimes because they were longstanding features of land use regulations of state property law existing as far back as colonial Boston, and New York enacted its first zoning ordinance in $1916{ }^{277}$ Short-term delays in improving property caused by zoning and permit regimes are longstanding features of state property law and are part of a landowner's reasonable investment-backed expectations. ${ }^{278}$ A moratorium prohibiting all economic uses for a period of six years is not a longstanding, implied limitation of state property law because "moratoria that prohibit all development do not have the lineage of permit and zoning requirements and thus it is less certain that the property is acquired under the 'implied limitation' of a moratorium prohibiting all development." 279

Chief Justice Rehnquist's dissent in Tahoe-Sierra helps identify regulations that are background principles of property law. ${ }^{280}$ Rehnquist accepted valid zoning and land-use regulations as background principles of state property law by explaining that "zoning and permit regimes are a

271 Id. at 768; see also Blumm \& Ritchie, supra note 206, at 341 (arguing property law can be used to defeat takings claims by the government).

272 See, e.g., Tahoe-Sierra Pres. Council, Inc. v. Tahoe Reg'l Planning Agency, 535 U.S. 302 (2002).

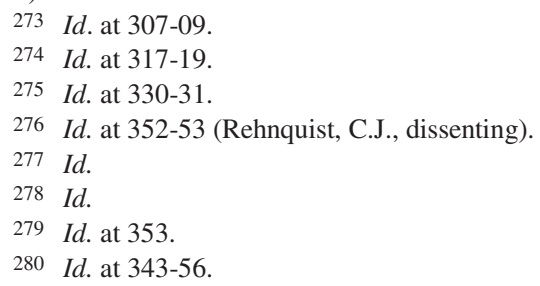


longstanding feature of state property law. ${ }^{281}$ Under Rehnquist's reasoning, statutes with land-use restrictions older than 1916 would qualify for immunity from takings liability. ${ }^{282}$ Regulations of wetlands that are critical to water resources and essential to public drinking would constitute a background principle of property law because regulations of wetlands have existed since $1899 .^{283}$ Although the CWA, NEPA, and other state statutes that regulate wetlands do not have the lineage of New York's first zoning ordinance in 1916, the Rivers and Harbors Act of 1899 helped provide the means for the establishment of the CWA. ${ }^{284}$ The Rivers and Harbors Act of 1899 contains wetland protection provisions and predates the $1916 \mathrm{New}$ York Zoning Ordinance. ${ }^{285}$ Under Rehnquist's dissent, wetland protection provisions are longstanding features of property law because of the Rivers and Harbors Act of $1899 .^{286}$

Statutes with land-use restrictions, which are not as longstanding as New York's first zoning ordinance, can also constitute background principles of property law if they are pre-existing at the time of purchase. Preexisting statutes in many jurisdictions constitute background principles of property law. ${ }^{287}$ An example of a pre-existing statute constituting a background principle of property law is the Federal Land Policy and Management Act of 1976 (FLPMA) in Reeves v. United States. ${ }^{288}$

In Reeves v. United States, the Court of Federal Claims held that the FLPMA's designation of the land in question, as a wilderness study, was a background principle of property law. ${ }^{289}$ There was not a taking because the

281 Id. at 352.

282 Blumm \& Ritchie, supra note 206, at 358.

283 See id.

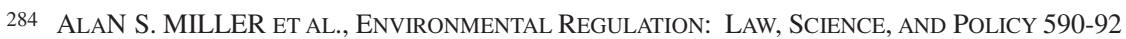
(Vicki Been \& Erwin Chemerinsky eds., Aspen Publishers 5th ed. 2006).

285 See Rivers and Harbors Appropriation Act of 1899, ch. 425, § 10, 30 Stat. 1151 (1899) (current version at 33 U.S.C. $§ 403$ (2000)); see also Blumm \& Ritchie, supra note 206, at 358. (noting that statutes and regulations ensuring wetland protection are examples that qualify for immunity from takings liability under Rehnquist's reasoning in his dissent).

286 Blumm \& Ritchie, supra note 206, at 358.

287 See, e.g., Kintross Copper Corp. v. Oregon, 981 P.2d 833, 840 (Or. Ct. App. 1999) (rejecting a mining company's challenge to a denial of a permit to discharge waste into the waters of the state by relying on the federal Desert Land Act of 1877); Gazza v. New York State Dep't. of Envtl. Conservation, 679 N.E.2d 1035, 1037 (N.Y. 1997) (ruling that the enforcement of an existing wetlands statutory restriction was not a taking); M \& J Coal Co. v. United States, 47 F.3d 1148, 1154 (Fed. Cir. 1995) (holding an existing statute constituted a background principle of property or nuisance law and the mining company knew or should have known it could not mine in a way that endangered public health or safety). See also Am. Pelagic Fishing Co. v. United States, 379 F.3d 1363 (Fed. Cir. 2004) (holding the Conservation Management Act was an existing rule sufficient to defeat a takings claim); Blumm \& Ritchie, supra note 206, at 357 n. 245 (2005).

288 See Reeves v. United States, 54 Fed. Cl. 652 (Fed. Cl. 2002).

289 Id. at 658-60. 
plaintiffs obtained their mining rights after the land was designated as a wilderness study; therefore, the plaintiffs did not have a property interest. ${ }^{290}$ The court explained that "[p]roperty interests are "created and their dimensions are defined by existing rules or understandings that stem from an independent source such as state law." ${ }^{291}$ The court further stated that the restricting source was the FLPMA, and that the nature of the plaintiffs' property interest was determined by the extent that the FLPMA could proscribe the use of the plaintiffs' mining claims. ${ }^{292}$ The court quoted Lucas, stating that the government "may resist compensation only if the logically antecedent inquiry into the nature of the owner's estate shows that the proscribed use interests were not part of his title to begin with." ${ }^{293}$ The FLPMA constituted a background principle of property law and was a defense to the takings claim. ${ }^{294}$

Regulations of wetlands restrict individual's property interests similar to the FLPMA in Reeves. ${ }^{295}$ If developers acquire their private property after regulations of wetlands are enacted, the regulations should not constitute a taking. ${ }^{296}$ Similar to Reeves, in which the plaintiffs did not have a property interest, developers should not have a property interest in developing wetlands if a regulation existed at the time of purchase. ${ }^{297}$ Wetland regulations, like the FLPMA in Reeves, should constitute a background principle of property law and a defense to a takings claim. ${ }^{298}$

Although Justice Scalia cautioned in Lucas against using legislatively decreed background principles, many post-Lucas courts agree with Justice Kennedy's concurrence that state and federal statutes function as takings defenses. ${ }^{299}$ Justice Kennedy disagreed with Justice Scalia that background principles cannot be newly legislated or decreed; instead, states should not be prevented from enacting new regulatory initiatives in response to changing conditions. ${ }^{300}$ While Justice Kennedy stated that preexisting statutes could constitute background principles, he appeared to change his opinion in the 2001 Supreme Court case, Palazzolo v. Rhode Island. ${ }^{301}$

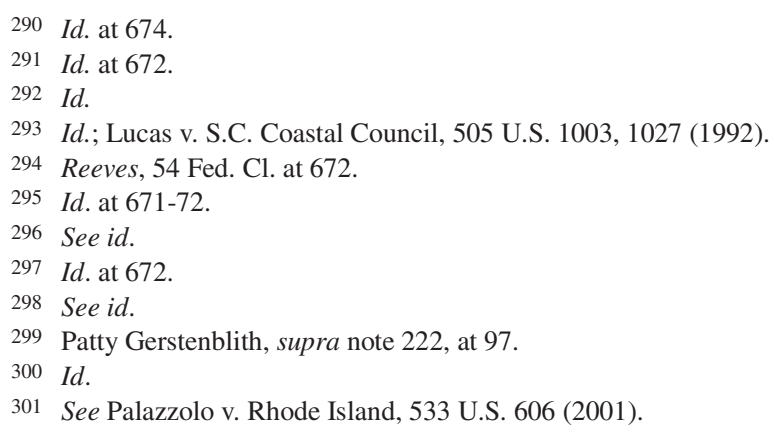


In Palazzolo v. Rhode Island, Justice Kennedy held that a preexisting statute did not constitute a takings defense. ${ }^{302}$ The plaintiff in that case, Anthony Palazzolo, wanted to develop his waterfront property in Rhode Island by filling in coastal marshlands to construct seventy-four homes, but he was denied a permit by the state agency in charge of enforcing laws regulating construction on the coast. ${ }^{303}$ Palazzolo argued that he was denied all economically viable use of his property, which constituted a taking, because he was not allowed to build anything on his waterfront property.

The Supreme Court reversed the Rhode Island Supreme Court's finding that states are insulated from takings claims because an owner acquired title after a regulatory law went into effect. ${ }^{305}$ It is important to note, however, that the majority opinion did not state that background principles could never include preexisting statutes and regulations but that some cannot defeat a takings claim at the threshold state. ${ }^{306}$ Preexisting law is frequently referred to as the notice rule: the enactment of a statute prior to an owner's acquisition of property defeats a takings challenge per se. However, this approach, generally adopted by lower courts, was precluded as a categorical approach in Palazzolo. ${ }^{307}$

Lucas's categorical defenses to takings claims include background principles of nuisance and property law. ${ }^{308}$ The dissent in Tahoe-Sierra helped identify background principles of property law when Chief Justice Rehnquist identified zoning and permit regimes as longstanding features of land use regulations of state property law. ${ }^{309}$ Background principles of property law could include wetland regulations because wetland regulations are longstanding features of land use regulations. ${ }^{310}$ Although Justice Scalia cautioned against legislatively decreed background principles, many courts follow Justice Kennedy's approach in Lucas, despite Palazzolo v. Rhode Island. Justice Kennedy did not state that all preexisting statutes cannot

302 See id.

303 Id. at 613-14.

304 Id. at 615-16.

305 Id. at 627 (arguing that "future generations, too, have a right to challenge unreasonable limitations on the use and value of land").

306 Blumm \& Ritchie, supra note 206, at 356.

307 Id. (noting that the majority opinion did not state that background principles can never include preexisting statutes and regulations, but that some background principles cannot defeat a takings claim at the threshold state).

308 Lucas, 505 U.S. at 1029-30.

309 Tahoe-Sierra Pres. Council, Inc., 535 U.S. at 352; Lucas, 505 U.S. at 1034 (Kennedy, J., concurring).

310 See Palazzolo v. Rhode Island, 533 U.S. 606, 627 (2001). 
constitute background principles, but that only some cannot. ${ }^{311}$ In addition to background principles of nuisance and property law, necessity should also defeat a takings claim. ${ }^{312}$

\section{c. Necessity - Miller v. Schoene}

Necessity should also defeat a takings claim. ${ }^{313}$ In Miller v. Schoene, owners of property with large ornamental red cedar trees were ordered to cut down the trees to prevent the spread of a rust or plant disease from the red cedar trees to apple orchards in the vicinity. ${ }^{314}$ The Court held, "[W]hen forced to [make] such a choice the state does not exceed its constitutional powers by deciding upon the destruction of one class of property in order to save another which, in the judgment of the legislature, is of greater value to the public." $" 315$ Thus, the ordering of the destruction of the cedar trees was not a taking because the cedar rust was fatal to apple trees nearby, which were of greater value to the public. The apple was one of the principal agricultural pursuits in Virginia, and millions of dollars were invested in the orchards. Whereas the apple furnished employment for a large portion of the population, the red cedar only had occasional use and value as lumber. ${ }^{316}$ The Court also stated that the question of whether the cedars constituted a nuisance, according to common law or as declared by statute, was irrelevant because the choice is controlled by considerations of social policy. ${ }^{31}$

Lucas's background principles of nuisance and property law should solve the problem of regulatory takings when private property owners are denied the ability to develop wetlands that are critical to water resources and essential for public drinking. ${ }^{318}$ Federal and state statutes, such as the CWA and the FERA, are existing rules that determine the nature of an individual's property interests. $^{319}$ The CWA and the FERA are only two examples that should constitute background principles of property law to defeat a takings claim. ${ }^{320}$ If an individual owned property before a regulatory initiative that protects wetlands was enacted, background principles of nuisance

311 Lucas, 505 U.S. at 1029 (announcing that background principles "cannot be newly legislated or decreed").

312 Blumm \& Ritchie, supra note 206, at 361-62.

313 See id.; see also Miller v. Schoene, 276 U.S. 272 (1928).

314 Miller, 276 U.S. at 277.

315 Id. at 279.

316 Id.

317 Id. at 280.

318 See Lucas, 505 U.S. at 1029-30.

319 Compare Sierra Club v. Flowers, 423 F. Supp. 2d 1273, 1313 (S.D. Fla. 2006) (articulating CWA determining the nature of an individual's property interests), with FLA STAT. $§ 373$ (setting forth an individual's property interests in legislation under FERA).

320 See Sierra, 423 F.Supp. 2d at 1313; See also FlA STAT. § 373. 
should defeat the takings claim. ${ }^{321}$ Developing wetlands that are critical to water resources and essential for public drinking should constitute a background principle of nuisance under Lucas. ${ }^{322}$ If neither background principles of nuisance nor property law can defeat a takings claim, necessity should. $^{323}$

Although Lucas's categorical defenses should solve the problem of regulatory takings, a few issues in Lucas remain unresolved. ${ }^{324}$ It appeared that the majority opinion in Lucas rejected the traditional nuisance defense found in Keystone, and also stated that background principles could be neither newly legislated nor decreed. ${ }^{325}$ If background principles cannot be newly legislated, then preexisting statutes, such as the CWA and the FERA, could not constitute a takings defense, and almost half of all property law would be neglected. $^{326}$ Although lower courts followed Justice Kennedy's approach in Lucas, that background principles could be legislatively decreed, in Palazzolo, Justice Kennedy held a different opinion.

Part V will argue that when Justice Scalia stated in Lucas that South Carolina must proffer more than the maxim "use what is yours so as not to harm what is others," he did not reject the nuisance defense in Keystone; rather, Scalia was requiring a narrower reading of the nuisance defense. ${ }^{328}$ The following section will also solve the problem of the apparent conflict between Justice Kennedy's concurrence in Lucas and his majority opinion in Palazzolo. ${ }^{329}$

\section{LuCAS's CATEGorical DefEnses Should SOlve the Problem of REGULATORY TAKINGS}

Lucas's categorical defenses should solve the problem of regulatory takings. ${ }^{330}$ The problems apparent in Sierra Club v. Strock and Florida Rock Industries v. United States will continue to reappear unless private

321 Blumm \& Ritchie, supra note 206, at 329.

322 See id. at 361-63; Lucas, 505 U.S. at 1029.

323 Blumm \& Ritchie, supra note 206, at 361-63.

324 See Blumm \& Ritchie, supra note 206, at 322.

325 Lucas, 505 U.S. at 1029-31; Blumm \& Ritchie, supra note 206, at 334.

326 See generally Lucas, 505 U.S. at 1029 (highlighting background principles).

327 See Lucas, 505 U.S at 1032-36. Contra Palazzolo v. Rhode Island, 533 U.S. 606, 629 (2001).

328 Compare Lucas, 505 U.S. at 1031 (inferring a more narrower reading of the nuisance defense but not outright rejection of the defense), with Keystone Bituminous Coal Ass'n v. DeBenedictis, 480 U.S. 470, 492-93 (1987) (finding public interest in preventing activities similar to public nuisances is a substantial one, which in many instances has not required compensation).

329 Compare Lucas, 505 U.S at 1032-36 (background principles can be legislatively decreed), with Palazzolo v. R.I., 533 U.S. 606 (2001) (background principles cannot be legislatively decreed).

330 See generally Blumm \& Ritchie, supra note 206, at 322-23 (discussing the categorical defenses in relation to regulatory takings). 
property owners, who threaten regulatory agencies with takings claims, are put on notice that they will be defeated by Lucas's categorical defenses. ${ }^{331}$ The interests of private property owners who wish to prosper through economic development are in conflict with the interests of those who wish to preserve wetlands. ${ }^{332}$ Developers should be put on notice that if they purchase wetlands that are critical to water resources and essential to public drinking, background principles of nuisance and property law will defeat any proffered takings claims.

Part V will show how Lucas's categorical defenses can defeat takings claims for those who are denied the ability to develop wetlands critical to water resources and essential to public drinking, despite the apparent conflict between Lucas and Keystone, and also despite the conflicting opinions of Justice Kennedy in Lucas and Palazzolo. ${ }^{334}$ Furthermore, Part V will resolve the apparent conflict between Lucas and Keystone by suggesting a narrow reading of the nuisance exception. ${ }^{335}$ Lastly, it will resolve the apparent conflict in Justice Kennedy's opinions in Lucas and Palazzolo by focusing on reasonable regulations.

\section{A. A Narrow Reading of the Nuisance Exception}

\section{Lucas v. S.C. Coastal Council}

In Lucas v. South Carolina Coastal Council, Justice Scalia stated, "South Carolina must do more than proffer the legislature's declaration that the uses Lucas desires are inconsistent with the public interest, or the conclusory assertion that they violate a common law maxim such as sic utere

331 See Sierra Club v. Flowers, 423 F. Supp. 2d 1273, 1313 (S.D. Fla. 2006); see also Florida Rock Indus. v. United States, 45 Fed. Cl. 21 (Fed. Cl. 1999).

332 Compare Hendler v. United States, 952 F.2d 1364, 1375 (1991) (arguing ownership of property is essential to economic development), with Gazza v. N.Y. State Dep't of Envtl. Conservation, 89 N.Y.2d 603, 617-20 (1997) (finding the preservation of wetlands outweighed person investment-backed expectations).

333 See Gazza, 89 N.Y.2d 617-20.

334 Compare Lucas, 505 U.S. at 1031 (inferring a narrower reading of the nuisance defense but not outright rejection of the defense), with Keystone Bituminous Coal Ass'n v. DeBenedictis, 480 U.S. 470, $492-93$ (1987) (finding a less narrow reading of the nuisance defense). Compare Lucas, 505 U.S at 1032-36 (arguing background principles could be legislatively decreed), with Palazzolo v. R.I., 533 U.S. 606 (2001) (arguing background principles should not be legislatively decreed).

335 Compare Lucas, 505 U.S. at 1031 (inferring a narrower reading of the nuisance defense but not outright rejection of the defense), with Keystone Bituminous Coal Ass'n, 480 U.S. at 492-93 (1987) (finding a less narrow reading of the nuisance defense).

336 Compare Lucas, 505 U.S at 1032-36 (arguing background principles could be legislatively decreed), with Palazzolo v. R.I., 533 U.S. 606 (2001) (arguing background principles should not be legislatively decreed). 
tuo ut alienum non laedas.",337 Instead, if South Carolina sought to restrain Lucas in a common law action for public nuisance, background principles of nuisance and property law that prohibit the uses Lucas intends must be identified. $^{338}$

In Justice Blackmun's dissent, he disagreed with Justice Scalia that South Carolina must identify background principles of nuisance and property law. ${ }^{339}$ Justice Blackmun stated that if the legislature was correct in finding the prohibition on building homes on coastal lots prevents serious harm, then the Act is constitutional. ${ }^{340}$ Justice Blackmun, citing Keystone Bituminous Coal Association v. DeBenedictis stated, "All property in this country is held under the implied obligation that the owner's use of it shall not be injurious to the community., ${ }^{, 31}$

\section{Keystone Bituminous Coal Association v. DeBenedictis}

In Keystone Bituminous Coal Association v. DeBenedictis, the enforcement of a law restricting the exercise of mineral rights, the Subsidence Act, was not a taking because it was designed to protect public health and safety. $^{342}$ The law restricted the exercise of mineral rights to prevent the subsidence of surface areas. ${ }^{343}$ Keystone protected regulations designed to prevent serious harm from takings liability. The majority stated, "[N]o individual has a right to use his property to create a nuisance or otherwise harm others." ${ }^{344}$ Rehnquist dissented, arguing that the nuisance exception to the requirement to compensate for taking was narrower than that suggested by the majority. ${ }^{345}$ In Rehnquist's view, the Court had become lenient in accepting government arguments that regulation was necessary to prevent harm to the public. ${ }^{346}$ Anything the government did under the police power to promote public health, welfare, and morals, could be articulated as a regulation to prevent harm because the concept of harm-prevention was coextensive with the police power. ${ }^{347}$

In Keystone, the purpose of the Subsidence Act included not only public safety, but also concern for the preservation of buildings, economic de-

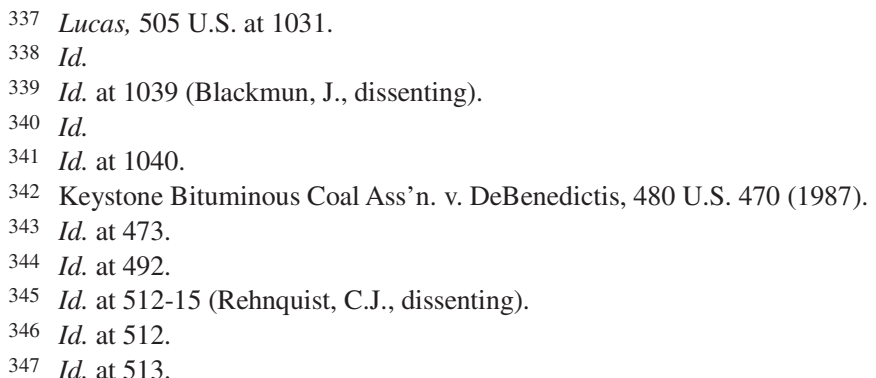


velopment, and enhancing the value of surface area lands for taxation. ${ }^{348}$ Rehnquist stated that the Subsidence Act was much more than a nuisance statute, and that the nuisance regulations exempted from the Fifth Amendment have rested on discrete and narrow purposes. ${ }^{349}$ A narrow reading of a harm-preventing regulation should meet the discrete and narrow purposes of nuisance regulations.

\section{Harm-Preventing Regulation}

Common law public and private nuisance law involves a determination of whether a particular use causes harm. ${ }^{350}$ A public nuisance is an unreasonable interference with a right common to the general public by interfering with the public health or safety. ${ }^{351}$ In Lucas, Justice Scalia seemed to be concerned with the fact that harm-preventing justifications could be formulated in practically every case, and that the distinction between harmpreventing and benefit-conferring regulation is in the eye of the beholder. ${ }^{352}$ Instead of reading Lucas to reject the nuisance exception of harmpreventing regulations found in Keystone, courts should read Lucas as requiring a narrower nuisance exception like Rehnquist argued for in Keystone. Justice Scalia's statement that South Carolina must proffer more than "use what is yours not to harm what is others," should be interpreted by courts as not rejecting the nuisance exception of harm-preventing regulations in Keystone, but as a narrower reading of harm-preventing regulations. A narrow reading of the harm exception will help distinguish between harm-preventing regulations and benefit-conferring regulations.

A regulation preventing imminent harm to public health or safety should qualify as a narrow reading of the harm exception. If an applicant for a section 404 permit under the CWA is denied a permit for the disposal of dredged or fill material onto wetlands, the denial should not constitute a taking if the wetland is critical to water resources and essential for public drinking. The denial of the permit would prevent harm to the public by preventing the applicant from interfering with water resources rather than a general benefit.

In Sierra Club v. Flowers, the denial of the permit to dredge wetlands should not constitute a taking because the approved mining was in close proximity to a wellfield from which drinking water was pumped daily. In

348 Id.

349 Id.

350 PERCIVAL ET AL., supra note 1, at 747.

351 RESTATEMENT (SECOND) OF TORTS § 821B (1979).

352 Lucas v. S.C. Coastal Council, 505 U.S. 1003, 1024 (1992); see also PerCIVAL, ET AL., supra note 1 at 751 . 
Sierra Club v. Strock, the court learned that benzene, a carcinogen, had been detected in the water being pumped from the Biscayne Aquifer, the primary source of drinking water for Miami-Dade County. ${ }^{353}$ The contamination was found where limestone mining occurred pursuant to the challenged permits. ${ }^{354}$ Limestone mining uses explosives that contain benzene to remove limestone from the Biscayne Aquifer. ${ }^{355}$ Benzene is a chemical known to cause cancer. ${ }^{356}$ The Miami-Dade County Water and Sewer Department (WASD), which is the agency responsible for delivering drinking water to Miami-Dade County, had to shut down seven production wells, known as the Northwest Wellfield, which draw water from the Aquifer and pump the water to water treatment plants. ${ }^{357}$ The Northwest Wellfield is Miami-Dade's largest single source of water supply and provides 155 million gallons of water per day to Miami-Dade County. ${ }^{358}$ It supplies approximately one million people with water. ${ }^{359}$

The denial of the permit under section 404 of the CWA to dredge the wetland for limestone should not constitute a taking because the mining causes imminent harm to public health. The contamination of water caused by the mining should qualify under the narrow reading of the harm exception. If the denial of the permit was not to prevent harm to the public's water supply, but to preserve wetlands for aesthetic and recreational concerns, then the denial should constitute a taking. The preservation of wetlands for aesthetic and recreational concerns would not qualify under the narrow reading of the harm exception. Instead it would qualify as a benefit to the public, in which compensation would be owed. ${ }^{360}$

In Florida Rock Industries, Inc. v. United States, the United States Court of Appeals for the Federal Circuit found that the Army Corps of Engineers denied the permit not to prevent harm, but to preserve wetlands for aesthetic and recreational concerns. ${ }^{361}$ The court stated that water pollution did not appear to be a problem at wells adjacent to pits and the concern of the Army Corps of Engineers was almost exclusively the continued existence of the wetland. ${ }^{362}$ The court stated:

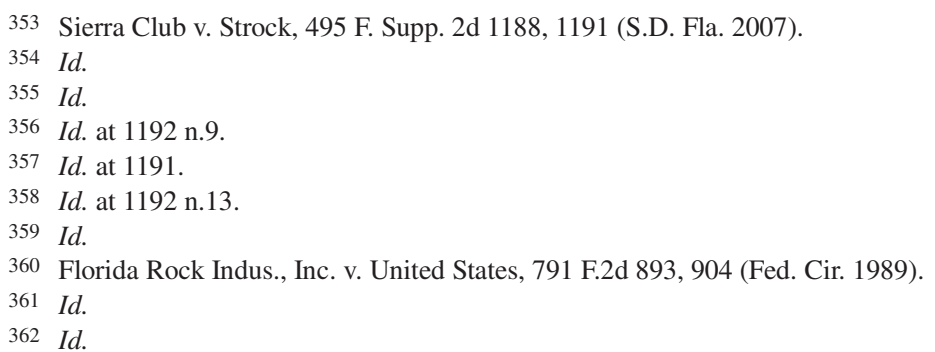


One who wanted to put toxic wastes in drinking water would encounter a balancing of public and private interests most unfavorable to his position and not likely to result in a compensation award. Denial of the permit frustrates him in doing harm. On the other hand, a moderate and pro forma polluter such as Florida Rock does no harm. Denial of the permit requires it to maintain at its own expense a facility, the wetlands, which by presently received wisdom operates for the public good, and benefits a large population who make no contribution to the expense of maintaining such facility. This appears to be a situation where the balancing of public and private interests reveals a private interest much more deserving of compensation for any loss actually incurred. ${ }^{363}$

A narrow reading of harm-preventing regulations should qualify as a categorical defense under Lucas. Regulations that prevent development of wetlands that are critical to water resources and essential to public drinking would not constitute a regulatory taking. A denial of a permit under the CWA or under FERA would not constitute a taking. The regulation would qualify under the narrow reading of harm-preventing regulations and, therefore, would qualify as a categorical defense under Lucas. Lucas's categorical defenses include not only nuisance defenses, but also background principles of property law.

\section{B. Background Principles of Property Law}

\section{Preexisting Statutes Should Serve as Constructive Notice}

In Lucas, Justice Scalia stated the limitation "cannot be newly legislated or decreed, but must inhere in title itself." ${ }^{364}$ Justice Kennedy concurred, but articulated the need to expand background principles further than common law in response to changing conditions. ${ }^{365}$ Although Justice Scalia cautioned against employing legislatively decreed background principles, many post-Lucas courts side with Justice Kennedy in his concurrence, holding state and federal statutes may function as a bar to takings challenges. ${ }^{366}$ Many jurisdictions hold that background principles of property law include preexisting statutes.

$363 I d$.

364 Lucas v. S.C. Coastal Council, 505 U.S. 1003, 1029 (1992).

365 Id. at 1035 (Kennedy, J., concurring).

366 Blumm \& Ritchie, supra note 206, at 354. 
In City of Virginia Beach v. Bell, a landowner was denied a permit to develop land by the city's Wetland Board. ${ }^{367}$ The landowner claimed the denial of the permit deprived him of all economically beneficial use and constituted a regulatory taking. ${ }^{368}$ The Circuit Court of the City of Virginia Beach awarded the landowner $\$ 110,000$ plus interest. ${ }^{369}$ On appeal, the court held that because the city's Coastal Primary Sand Dune Zoning Ordinance pre-dated the landowner's acquisition of property, denial of the permit was not a compensable taking.

In Kim v. City of New York, a public road in Queens was re-graded. ${ }^{371}$ The city placed side fill on a portion of the plaintiff's property to maintain lateral support for a road. ${ }^{372}$ Plaintiffs alleged they were entitled to compensation for the portion of the property taken by the fill. ${ }^{373}$ The court disagreed, holding that "in identifying background rules of state property law that inhere in owner's title, for purposes of determining whether property owner ever possessed property interest allegedly taken by government action, courts should look to law in force, whatever its source, when owner acquired property." A charter imposed obligations on property owners to maintain lateral support for a public highway when the plaintiffs acquired their property. ${ }^{375}$ The city's subsequent enforcement of the obligation did not constitute a taking because the plaintiffs acquired their property with constructive notice that the property abutted a public road. ${ }^{376}$ By raising a portion of the plaintiffs' property up to a legal grade, the city acted in conformity with a provision of its charter that was in force when the plaintiffs acquired their property.

Similar to City of Virginia Beach v. Bell and Kim v. City of New York, in which pre-existing laws constituted background principles of property law, regulations of wetlands that exist at the time of an owner's purchase of property should also constitute background principles of property law. Categorical exceptions should include pre-existing statutes and regulations to respond to changing conditions. Courts should follow the reasoning of Justice Kennedy and lower courts. One changing condition is the critical role

367 City of Virginia Beach v. Bell, 498 S.E.2d 414, 415 (Va. 1998).

368 Id.

369 Id. at 416.

370 Id. at 417.

371 Kim v. City of New York, 681 N.E.2d 312, 313 (N.Y. 1997).

372 Id.

373 Id.

374 Id. at 316.

375 Id. at 313 .

376 Id. at 318 .

377 Id. at 321; see also Hunziker v. Iowa, 519 N.W.2d 367, 370-71 (Iowa 1994) (holding a preexisting state statute was a Lucas background principle). 
wetlands play in preserving water quality and quantity. Throughout history, wetlands were drained and developed because they were considered a nuisance. Now, in response to water shortages and population growth, people realize the importance of preserving wetlands. All landowners who acquire wetlands after federal or state statutes are enacted should acquire their property with constructive notice that the pre-existing law will defeat a takings challenge per se if any restrictions on their property are challenged. The CWA, NEPA, and FERA are just a few statutes that should serve as constructive notice to property owners who acquire property after their enactment.

\section{The Solution to Palazzolo v. Rhode Island}

In Palazzolo v. Rhode Island, Justice Kennedy held that a preexisting wetland regulation did not constitute a takings defense. ${ }^{378}$ Justice Kennedy $^{2}$ explained, "Future generations, too, have a right to challenge unreasonable limitations on the use and value of land."379 Palazzolo v. Rhode Island did not state background principles could never include preexisting statutes and regulations, but that some cannot defeat a takings claim. ${ }^{380}$ The preexisting wetland regulation in Palazzolo was one of the regulations that could not defeat a takings claim. Justice Kennedy was concerned with unreasonable preexisting statutes and regulations. Justice Kennedy stated, "The Takings Clause, however, in certain circumstances allows a landowner to assert that a particular exercise of the State's regulatory power is so unreasonable or onerous as to compel compensation." 381 This statement should not be read to counter what Justice Kennedy said when concurring in Lucas. Instead, the statement should be read to narrow what Justice Kennedy said earlier in Lucas. Federal and state statutes may function as a bar to takings challenges, but only if they are reasonable.

A legislative enactment can constitute a background principle depending on the circumstances involved. The legislative enactment must be based on permissible limitations. ${ }^{382}$ The Court stated:

We have no occasion to consider the precise circumstances when a legislative enactment can be deemed a background principle of state law or whether those circumstances are present here. . . . The determination whether an existing, general law can limit all economic use of

\footnotetext{
378 Palazzolo v. Rhode Island, 533 U.S. 606, 632 (2001).

379 Id. at 627 (emphasis added).

380 Blumm \& Ritchie, supra note 206, at 356.

381 Palazzolo, 533 U.S. at 627 (emphasis added).

382 Id. at 630.
} 
property must turn on objective factors, such as the nature of the land use proscribed. $^{383}$

Regulations that prevent development of wetlands that are critical to water resources and essential to public drinking are reasonable. If an individual is denied a permit to develop wetlands, the denial should not constitute a taking because the regulation is reasonable. In every continent, important aquifers are falling. ${ }^{384}$ Less than one-third of the world's population benefits from ample water supplies. ${ }^{385}$ Some studies predict that by the year 2025, almost $50 \%$ of the world's population will be living in water shortage areas. $^{386}$ On a finite planet, economic production must inevitably deplete natural resources. ${ }^{387}$ Instead of this happening presently, it can happen in the far distant future by preserving wetlands. ${ }^{388}$ If one is denied a permit under the CWA or FERA, the denial should not constitute a taking. The CWA and FERA should constitute background principles of property law under Lucas. If one purchases property before a regulation is enacted, it would not constitute a background principle under Lucas. If the defense of background principles of nuisance or property law does not exist, then necessity should defeat a takings claim.

\section{Necessity - Miller v. Schoene}

In Miller v. Schoene, ordering the destruction of cedar trees was not a $\operatorname{taking}_{389}$ because it was fatal to apple trees, which were of greater public value. The Court also found it unnecessary to "weigh with nicety the question whether the infected cedars constitute a nuisance according to common law; or whether they may be so declared by statute" because the choice is controlled by considerations of social policy.

Similar to Miller v. Schoene, public necessity should defeat a takings claim for challenges to wetland regulations. Freshwater shortages threaten the living world by causing hunger and then thirst. ${ }^{391}$ A water shortage would cause hunger before thirst because the dominant use of water is in agriculture. $^{392}$ Water shortages can be prevented by preserving wetlands

\footnotetext{
383 Id.; see generally PERCIVAL ET AL., supra note 1, at 750-61.

384 Palazzolo, 533 U.S. at 117.

385 Id.

386 Id.

387 Id. at 122.

388 See generally id. (stating that the real question is when it must come to an end, whether this must happen soon, or in the far distant future).

389 Miller v. Schoene, 276 U.S. 272, 279 (1928).

390 Id. at 280.

391 DALY \& FARLEY, supra note 69, at 116

392 Id.
} 
because wetlands provide water purification and groundwater recharge. ${ }^{393}$ Wetland regulations that destroy property value to protect water resources are within the public interest and should be immune from takings liability because of public necessity. Similar to Miller v. Schoene, in which apple trees were of greater value to the public, water is of much greater value than economic production. Water is $100 \%$ essential to human survival and is non-substitutable.

\section{CONCLUSION}

Millions of acres of wetlands in the United States have been destroyed. The growing awareness of the importance of wetlands and the consequences of their destruction has led to significant governmental regulations to preserve wetlands. Efforts to protect wetlands occur at the national, state, and international levels. The NEPA, CWA, EWRA, and many other initiatives provide for the protection of wetlands at the national level. The FWRA of 1972, the FERA of 1975 and 1993, the Warren S. Henderson Wetlands Protection Act of 1984, and many other Acts provide for protection at Florida's state level. At the international level, the Ramsar Convention provides for the protection of wetlands.

Despite the many efforts to protect wetlands, wetlands are threatened by regulatory takings claims. Private property owners threaten the effectiveness of wetland regulations by claiming unconstitutional takings. If regulatory agencies in charge of enforcing regulations that protect wetlands are threatened with takings claims, the agencies might negotiate with private property owners instead of protecting wetlands. This occurred in Sierra Club v. Flowers and Sierra Club v. Strock.

Lucas v. South Carolina Coastal Council's background principles of nuisance and property law should solve the problem of regulatory takings when private property owners are denied the ability to develop wetlands that are critical to water resources and essential for public drinking. Lucas created numerous categorical defenses in which governmental defendants could defeat takings claims. The categorical defenses of background principles of nuisance and property law should include regulations of wetlands that are critical to water resources and essential for public drinking. Background principles of nuisance should include wetland regulations that are critical to water resources because development would create a significant

393 FREEMAN \& KolstAD, supra note 65, at 323; see also DALY \& FARLEY, supra note 69, at 117 (stating that the "World Bank warns that continued reduction in aquifers could prove catastrophic. Fortune magazine suggests that water shortages will make water the oil of the twenty-first century.").

394 DALY \& FARLEY, supra note 69, at 196. 
degree of harm to public resources. Development of wetlands critical to water resources can contaminate the public's drinking water supply. The regulations will prevent harm to the public health by preventing individuals from interfering with the public's water resources. The regulation would also qualify under the narrow reading of harm-preventing regulations and, therefore, would qualify as a categorical defense under Lucas.

Background principles of property law should also include wetland regulations, such as the CWA and FERA. Wetland regulations existed as far back as 1899 and are longstanding features of property law. Background principles of property law should also include preexisting statutes. The CWA and FERA are examples of preexisting statutes that could defeat a takings claim if the landowner acquired their property after the enactment of the CWA or the FERA, and the regulations are reasonable. Regulations that prevent development to wetlands that are critical to water resources and essential for public drinking are reasonable because the regulations help prevent water shortages and water contamination.

Another defense to regulations of wetlands that are critical to water resources includes necessity. Although necessity was not apparent in Lucas, it was in Miller v. Schoene. Water is of much greater public value than economic development because it is essential to human survival and is not substitutable. 